This PDF is a selection from an out-of-print volume from the National Bureau of Economic Research

Volume Title: Long-Range Economic Projection

Volume Author/Editor: Conference on Research in Income and Wealth

Volume Publisher: NBER

Volume ISBN: 0-691-04141-5

Volume URL: http://www.nber.org/books/unkn54-1

Publication Date: 1954

Chapter Title: Specific Industry Output Projections

Chapter Author: Harold J. Barnett

Chapter URL: http://www.nber.org/chapters/c2934

Chapter pages in book: (p. 191 - 232) 


\title{
SPECIFIC INDUSTRY OUTPUT PROJECTIONS
}

\author{
HAROLD J. BARNETT \\ RAND CORPORATION
}

\section{A. ALTERNATIVE PROJECTIONS}

LET us assume that the time is the beginning of 1947. We have just completed the first full-scale projections of industrial output employing an input-output matrix to calculate derived demand. Our article, which presents outputs by industries for 1950, has been sent to the publisher. ${ }^{1}$

In the projections we used a matrix about $40 \times 40$ in size consisting of 1939 input-output coefficients. An attempt was made ". . . to correct the 1939 input ratios for a few clearly discernible changes. . . . ${ }^{2}$ These adjustments were made partly on the basis of past trends, partly in consultation with experts. Clearly, changes in addition to these may occur by 1950; but there is no present basis for estimating even roughly their nature, direction, or magnitude."

After consideration of population size, labor force, productivity changes by industries, and other variables, we estimated that 1950 gross national product (in 1939 prices) would be about 86 percent greater than that for 1939 if final demand represented a consumption model, and 79 percent greater if final demand represented an investment model. ${ }^{4}$ We inserted our alternative final demands in the revised matrix, solved the simultaneous equations, and,

Note: I am indebted to a major degree to Ronald Shephard, Russell Nichols, Andrew Marshall, Roland McKean, Sam Schurr, and Alice Hirsch. In addition I have benefited from useful comment from Joseph Kershaw, Marvin Hoffenberg, W. Evans, and E. M. Hoover.

1 J. Cornfield, W. Evans, and M. Hoffenberg, "Full Employment Patterns, 1950," Monthly Labor Review, February and March 1947; reprinted in pamphlet form in 1947 with the same title by the Government Printing Office, Washington. Also Appendix A thereto (mimeographed, May 1946).

2 "These [were]:

“(1) A 25 percent reduction in unit coal consumption by railroads.

“(2) A 650 percent increase in unit diesel oil consumption by railroads.

“(3) A 20 percent increase in the amount of textile fiber per tire with 60 percent of the fiber supplied by cotton, 40 percent by synthetics.

"(4) A continuation of the prewar trend toward the substitution of synthetic fibers for cotton in apparel."

${ }^{3}$ Cornfield, Evans, and Hoffenberg, op.cit., Appendix A, p. 17.

4 Percentages furnished by Marvin Hoffenberg. 


\section{SPECIFIC INDUSTRY OUTPUT}

after a certain amount of recycling to satisfy the assumption of full employment, arrived at two sets of projected 1950 outputs by industries.

At this point we say to ourselves: Let us make projections by alternative techniques using certain basic assumptions identical with those employed for the input-output projections. We shall file them in a folder marked "not to be opened until 1951." In 1951 we shall compare the projections with actual outputs by industries, and discover the deviations from actual of the various projections.

Which alternative techniques shall we use? One technique in general use is multiple correlation. For these individual industry or commodity projections, we shall arbitrarily use the same relationship for all:

$$
\text { Specific industry output }=a+b \text { GNP }+c \text { time }
$$

For the historical periods, we shall arbitrarily use the periods 1922-41 and 1946 for each industry or commodity. The gross national products projected will, of course, be those used in the Full Employment Patterins, 1950 projections (186 percent and 179 percent of 1939). We will refer to projections derived by this technique as multiple regression projections.

Our second alternative technique will be simple. We shall assume that

$$
\frac{\text { Projected industry output in } 1950}{\text { Actual industry output in } 1939}=\frac{\text { Projected GNP in } 1950}{\text { Actual GNP in } 1939}
$$

With an 86 or 79 percent increase in GNP by 1950, this technique results in projected increases in the output of every specific industry of exactly 86 or 79 percent. We shall refer to these projections as GNP blowups.

Our third alternative is also simple. To employ the input-output matrix used in the Full Employment Patterns, 1950 projections for estimating derived demand, it was necessary to estimate final demand for the output of each industry. These demand estimates reflecting income elasticity were made according to universal estimating practice-regression analysis, budget studies, arbitrary assumption about the government budget, etc.-and had nothing to do with the input-output matrix, beyond uniformity of industry classification. For example, 1950 final demand for agricultural and fishing output was estimated at 52 percent 
over 1939 for a consumption-oriented economy and at 35 percent over 1939 for an investment-oriented economy. For ferrous metals, the same estimates were 94 and 139 percent, and for chemicals, 89 and 83 percent. $^{5}$ For this third alternative technique, we assume an increase in the total output of each industry equal to the percentage increase in final demand for the output of that industry. Thus, using the above examples, we project (with $1939=$ 100) the following:

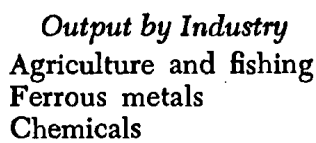

$\begin{array}{cc}\begin{array}{c}\text { Consumption } \\ \text { Model }\end{array} & \begin{array}{c}\text { Investment } \\ \text { Model }\end{array} \\ 152 & 135 \\ 194 & 239 \\ 189 & 183\end{array}$

Projections by this technique (in which we employ final demand structures identical with those to which the input-output matrix in Full Employment Patterns, 1950 was hinged) will be called final demand blowups.

\section{B. COMPARING 1950 PROJECTIONS WITH ACTUAL}

The time is now 1951 and the results of the Full Employment Patterns, 1950 (FEP) and alternative projections may be presented and compared with the 1950 actual. ${ }^{8}$ Table 1 , in millions of 1939 dollars, compares actual 1950 output with the eight output projections produced by the published article and the three alternative techniques. Table 2 presents the same information in index numbers, with $1939=100$. Tables 3 and 4 present deviations of the eight projections from the actual, in millions of 1939 dollars and in index number points, with $1939=100$. These tables also present arithmetic means of the errors in the several projections.

${ }^{5}$ Cornfield, Evans, and Hoffenberg, op.cit, table 14, p. 34.

${ }^{6}$ See Appendix for basic data, sources, and details of computation. 


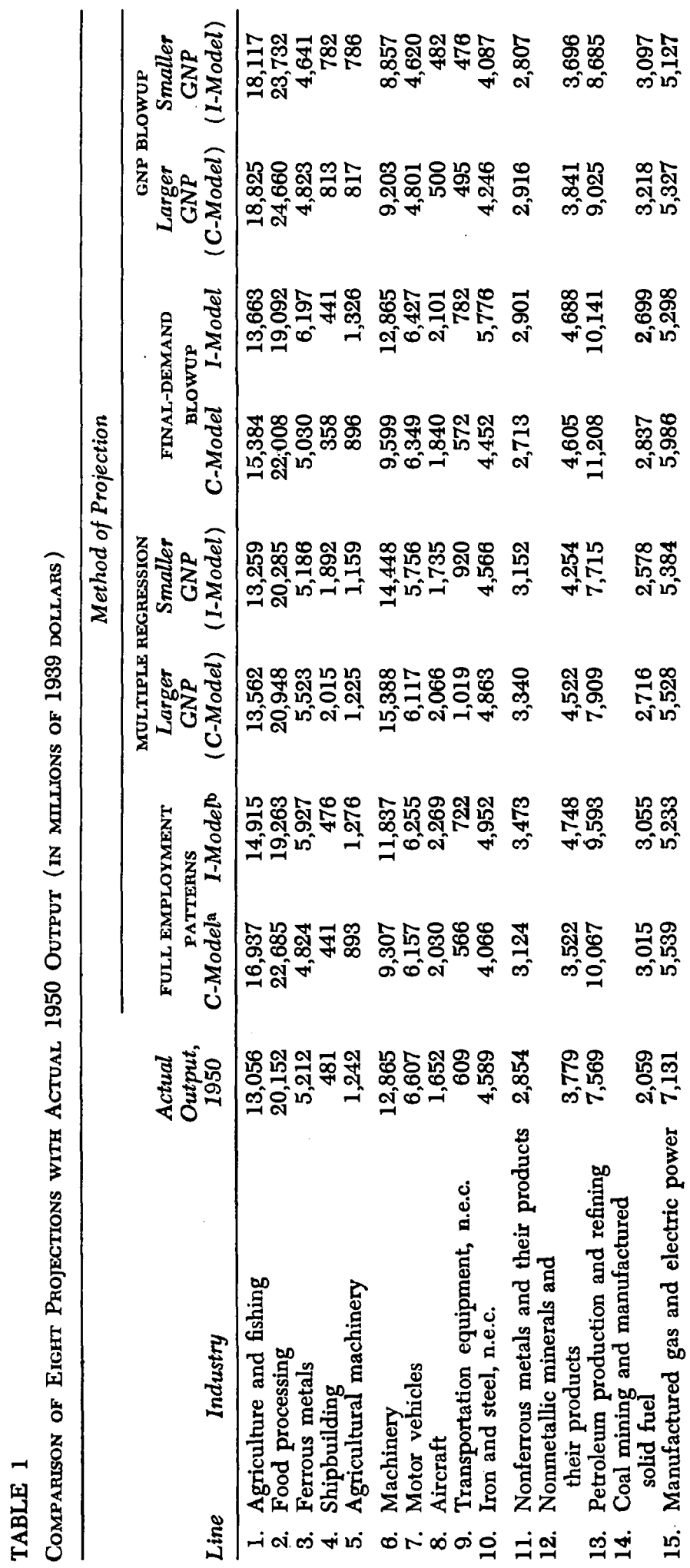




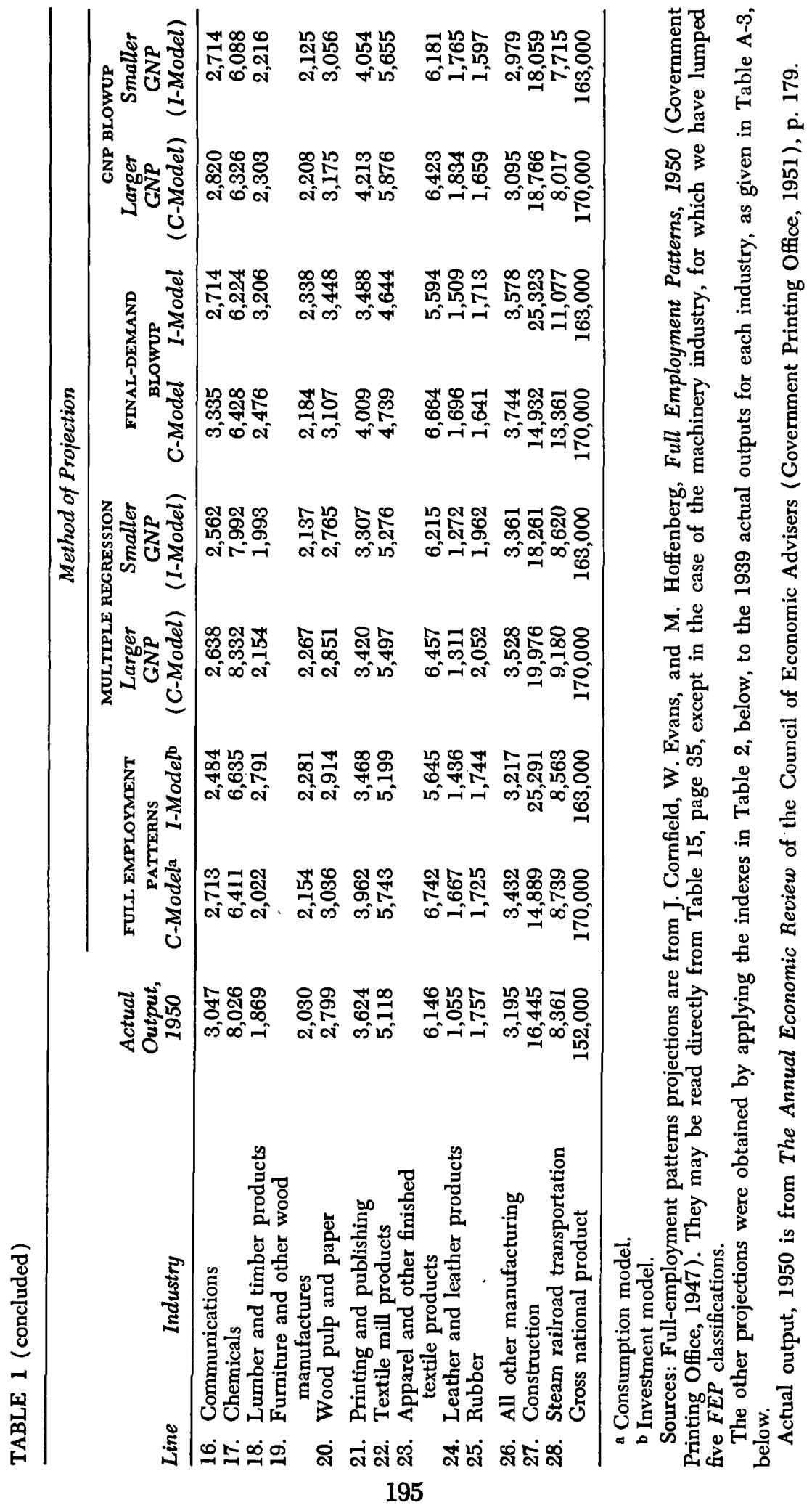


SPECIFIC INDUSTRY OUTPUT

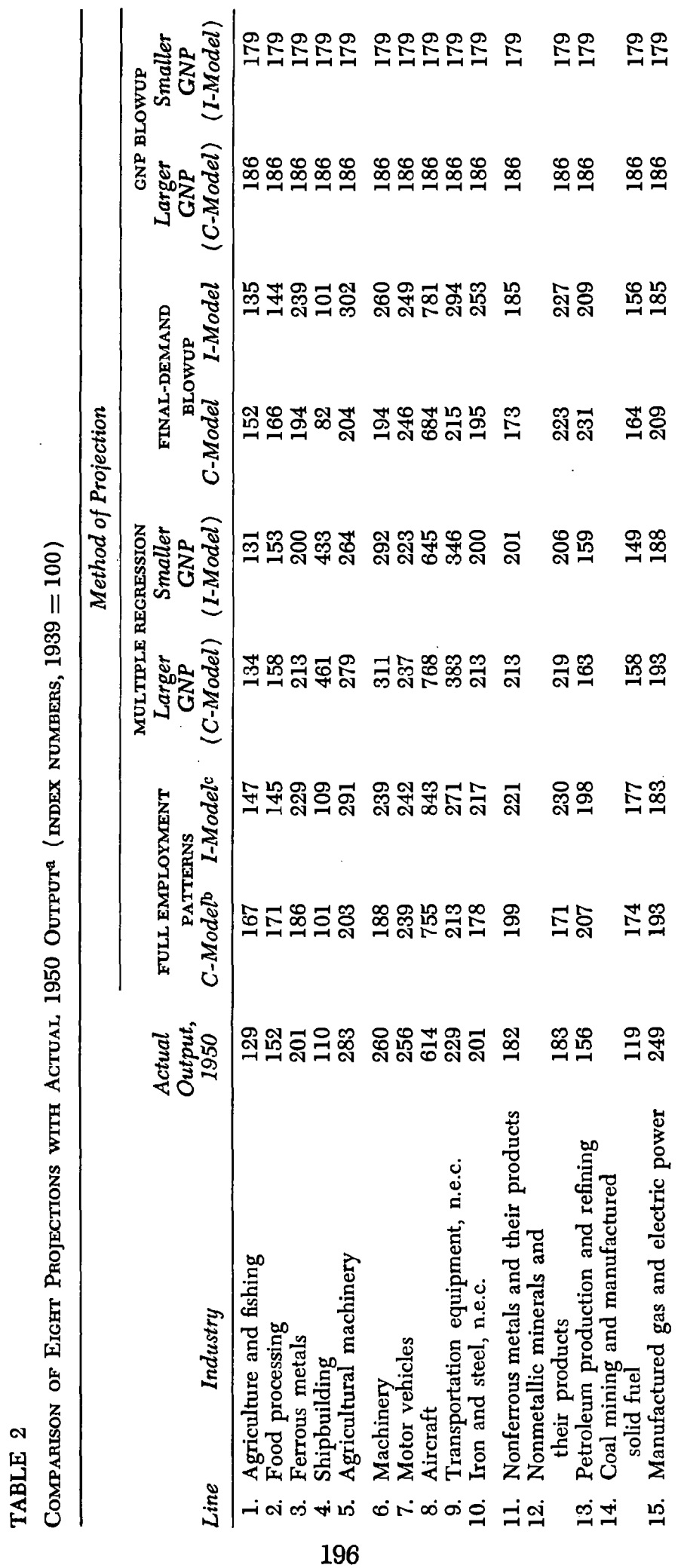


SPECIFIC INDUSTRY OUTPUT

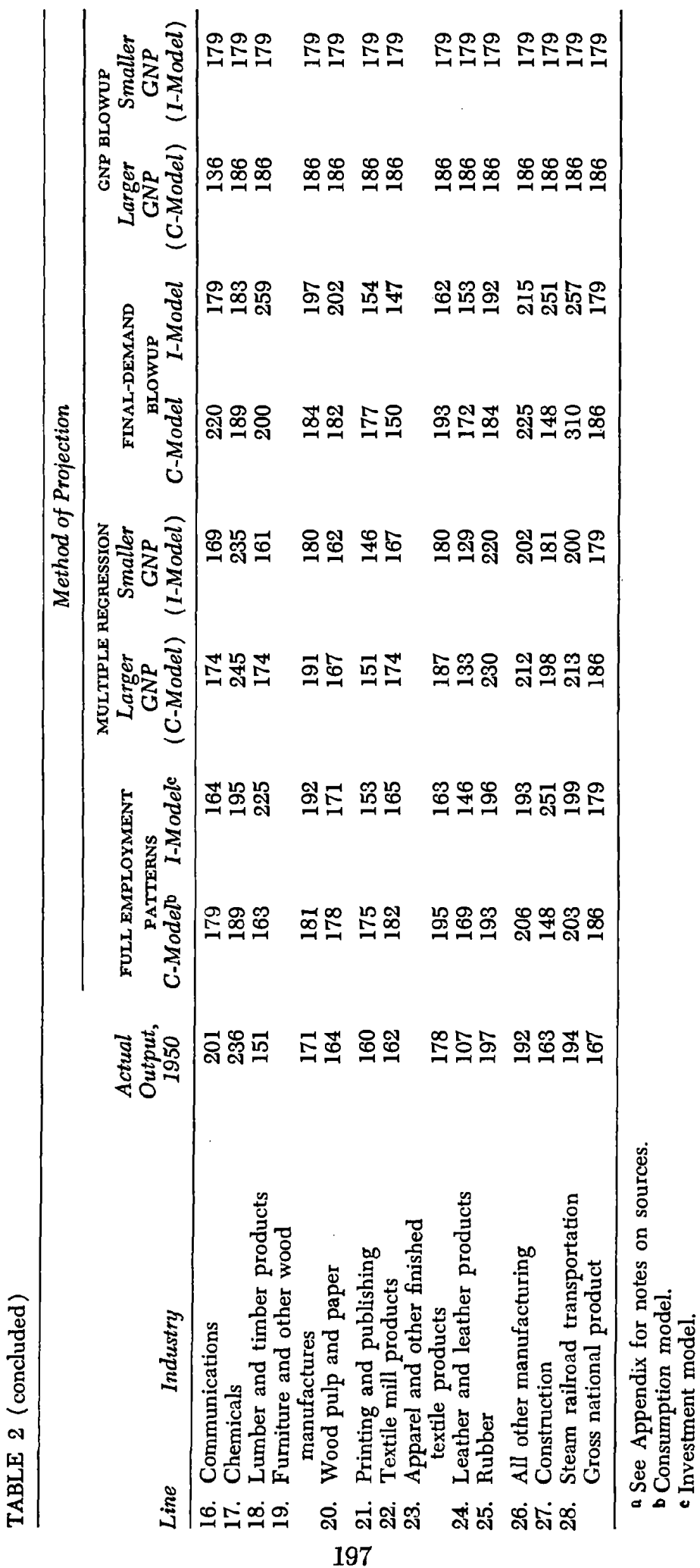




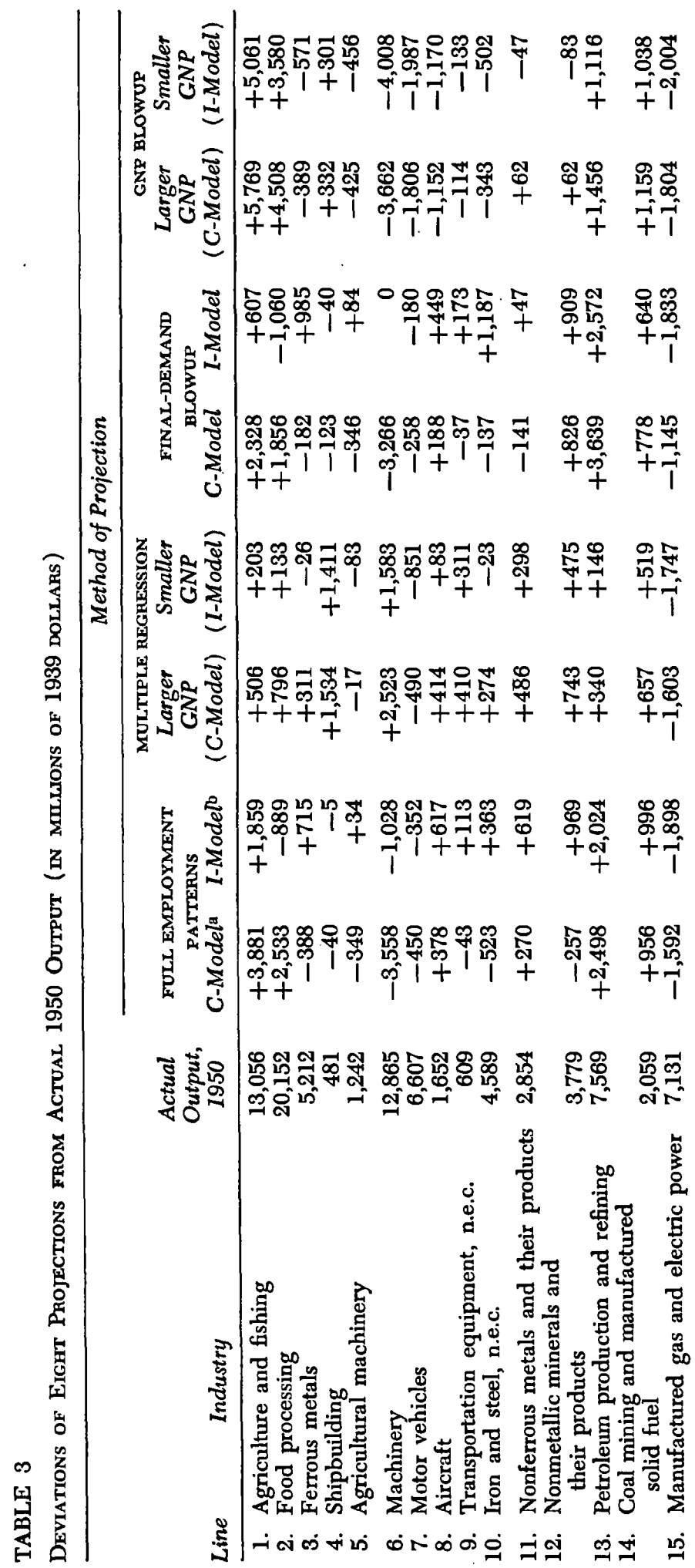




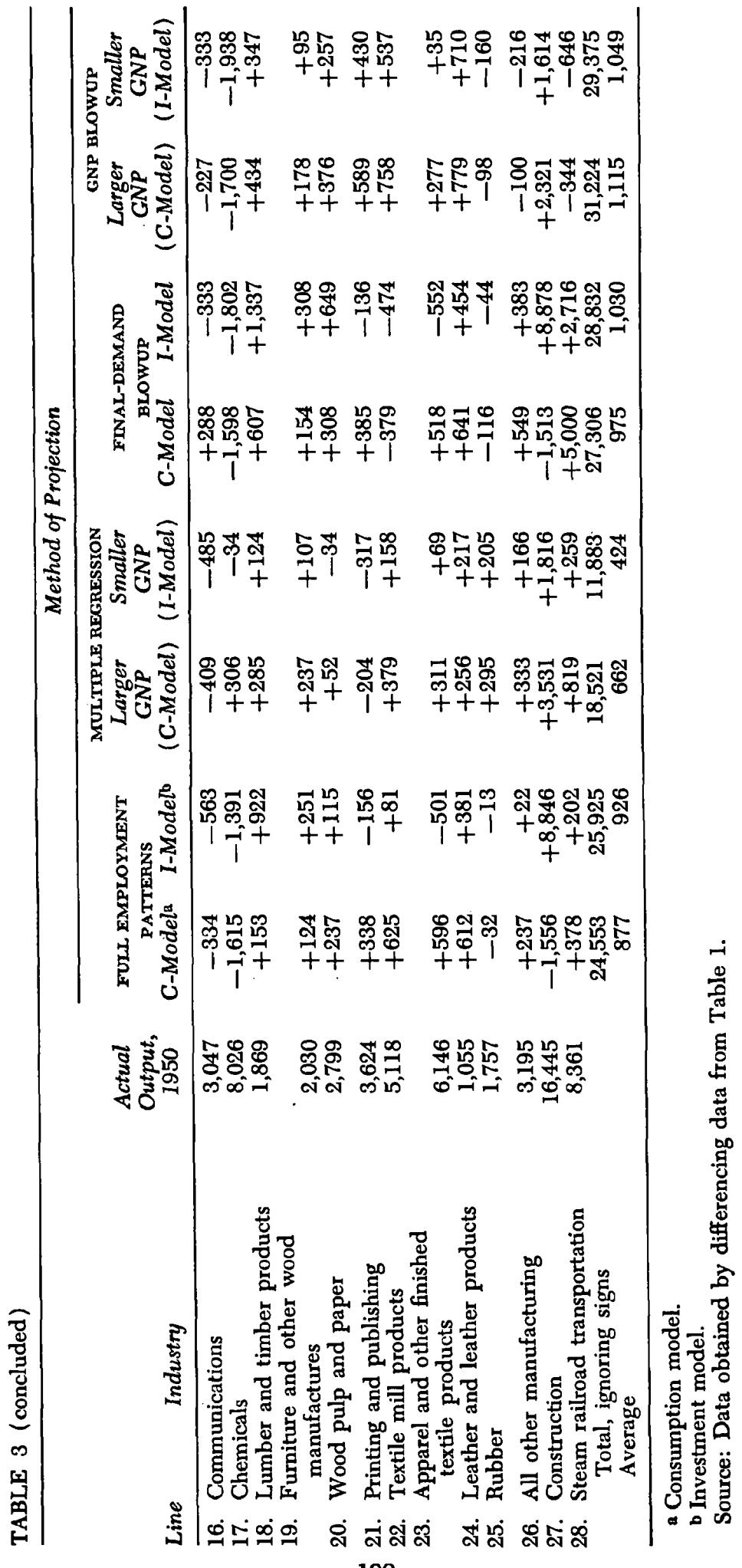




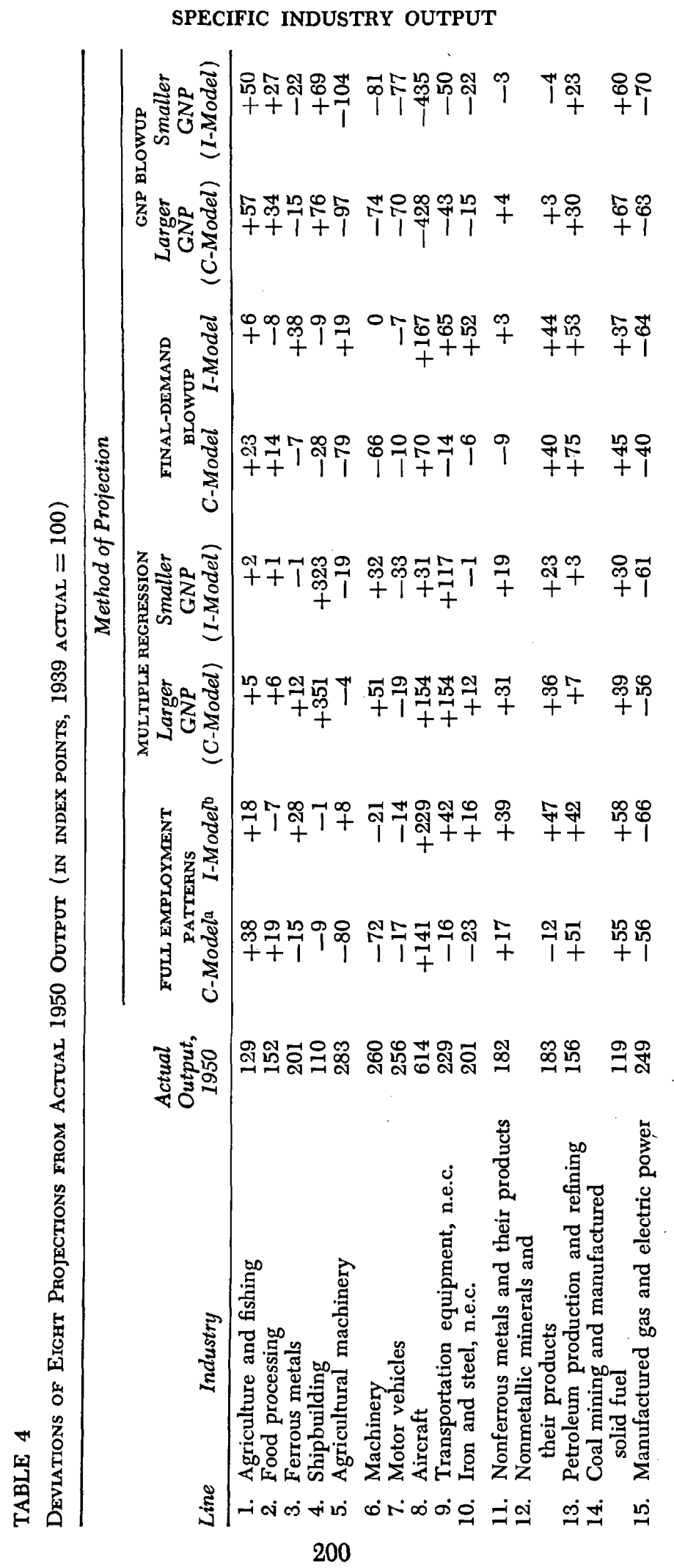


SPECIFIC INDUSTRY OUTPUT

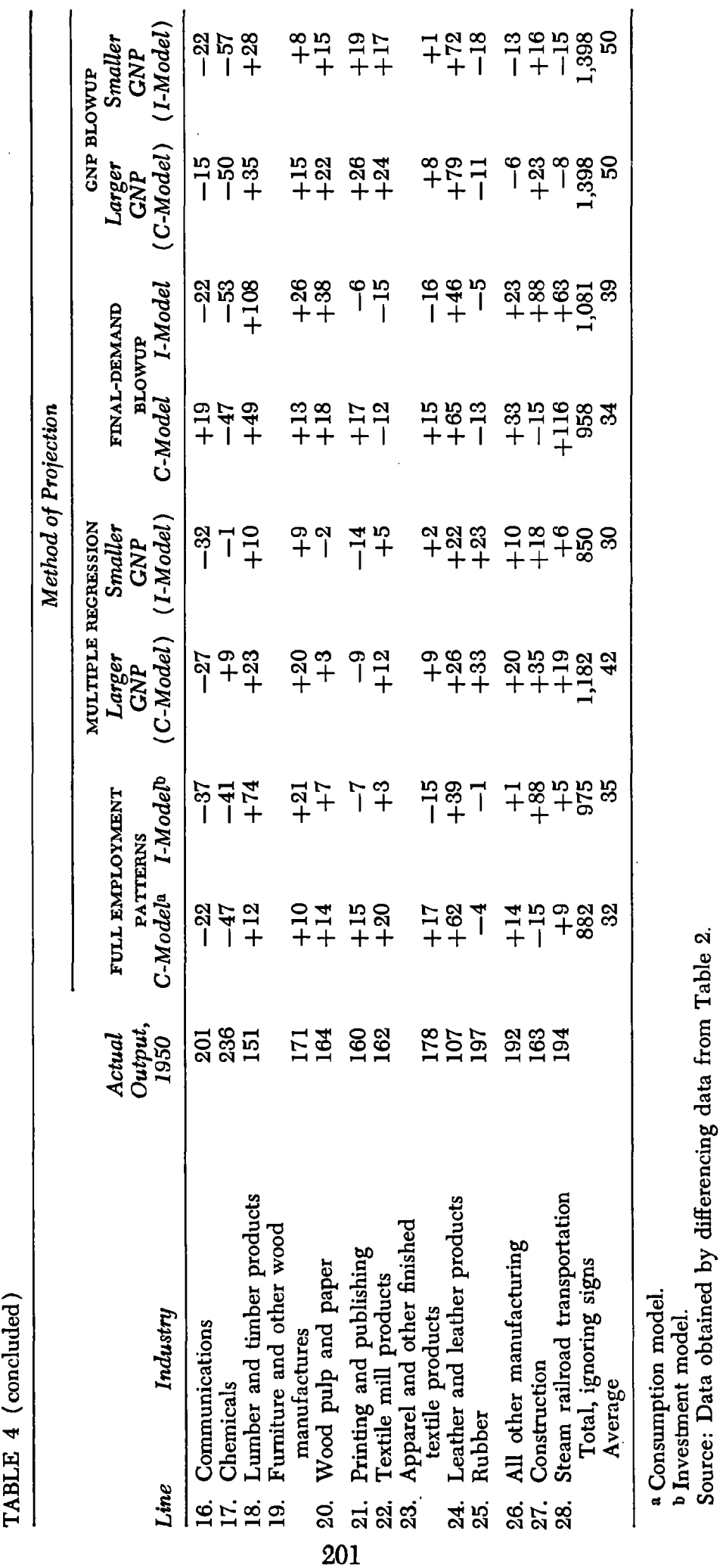


The most obvious results are the mean errors. These, expressed as percentages of value of industry output in 1939, are as follows:

\begin{tabular}{llcc} 
& & \multicolumn{2}{c}{ MEAN ERRORS-PERCENT OF VALUE OF } \\
INDUSTRY OUTPUT IN 1939 \\
Weighted by Specified \\
PROJECTION TECHNIQUE \\
USED & \multicolumn{1}{c}{$\begin{array}{c}\text { Industry Value } \\
\text { of Output, 1939 }\end{array}$} & Unweighted \\
Multiple regression & Investment & 14 & 30 \\
Multiple regression & Consumption & 22 & 42 \\
Full Employment Patterns & Consumption & 29 & 32 \\
Full Employment Patterns & Investment & 30 & 35 \\
Final-demand blowup & Consumption & 32 & 34 \\
Final-demand blowup & Investment & 34 & 39 \\
GNP blowup & Investment & 34 & 50 \\
GNP blowup & Consumption & 36 & 50
\end{tabular}

Which of the mean errors-weighted or unweighted-is more important depends on one's specific projection interest. If interest centers on individual industries, the unweighted mean comparison is more relevant. But means do not fully describe the error patterns. Frequency distribution charts ( 1 through 4 ) and tables (5 and 6 ) yield additional information on the error patterns. These appear to indicate the following:

1. With respect to dollar projections, equivalent to the weighted mean comparison above, and confirming the results indicated by the means, the descending order of "goodness" of these particular projections is: (a) multiple regression; (b) Full Employment Patterns, 1950; (c) final-demand blowup; and (d) GNP blowup.

The horizontal lines on Table 5 indicate the size of error reached by the time the best 23 and 26 cases, respectively, are included. The above order of "goodness" (minimal dispersion) holds when five and two extreme errors in each projection are discarded, as well as when no cases are discarded.

2. For unweighted projections, the results are more equivocal. The horizontal lines on Table 6 are used as they were in Table 5. If five extreme errors in each projection are discarded, multiple regression and Full Employment Patterns, 1950 projections are somewhat better than final-demand blowup and GNP blowup projections. If two extreme cases are discarded, multiple regression projections become inferior to the others, and FEP projections become best. If all cases are included, errors of FEP and final-demand blowup projections are less dispersed than those 
of multiple regression and GNP blowup projections. These differing dispersions result in the means indicated above and in Table 4, in which FEP, multiple regression, and final-demand blowup projections are all of approximately equal error, and GNP blowup projections have greater error.

There may be some interest in a classified list of the industries in which each projection was best. In the list below, I have ignored GNP blowups and final-demand blowup projections, in the belief that these are crude approximations of the multiple regression and the FEP projections, respectively. The list is as follows:

\begin{tabular}{|c|c|c|}
\hline $\begin{array}{l}\text { Full Employment } \\
\text { Patterns } \\
\text { (Consumption Model) }\end{array}$ & $\begin{array}{l}\text { Full Employment } \\
\text { Patterns } \\
\text { (Investment Model) }\end{array}$ & $\begin{array}{l}\text { Regression, } \\
\text { Smaller GNP }\end{array}$ \\
\hline $\begin{array}{l}\text { Transportation } \\
\text { equipment, n.e.c. } \\
\text { Nonferrous metals } \\
\text { \& their products } \\
\text { Communications } \\
\text { Construction }\end{array}$ & $\begin{array}{l}\text { Shipbuilding } \\
\text { Machinery } \\
\text { Motor vehicles } \\
\text { Printing \& publishing } \\
\text { Textile mill products } \\
\text { Rubber } \\
\text { All other manufactur- } \\
\text { ing } \\
\text { Steam railroad trans- } \\
\text { portation }\end{array}$ & $\begin{array}{l}\text { Agriculture \& fishing } \\
\text { Food processing } \\
\text { Ferrous metals } \\
\text { Aircraft } \\
\text { Iron \& steel, n.e.c. } \\
\text { Petroleum production } \\
\quad \text { \& refining } \\
\text { Coal mining } \\
\text { Chemicals } \\
\text { Lumber \& timber products } \\
\text { Furniture \& other wood } \\
\text { manufactures } \\
\text { Wood pulp \& paper } \\
\text { Apparel } \\
\text { Leather }\end{array}$ \\
\hline
\end{tabular}

The list excludes manufactured gas and electric power, in which FEP projections (consumption model) and regression projections (larger GNP) were tied; and agricultural machinery, where regression projections (larger GNP) were best. If these are included, regression projections are better in 14 industries, FEP projections are better in 13 industries, and both are equally poor in 1 .

\section{QUALIFICATIONS}

At various times in the preparation of these data, I found myself wondering whether I was testing projections or testing the quality of the index numbers which record the "actual." This problem was aggravated by the fact that I had to match actual 1950 "physical" outputs with the industrial classifications used in Full Employment Patterns, 1950, and these classifications are not homogeneous. The first qualification, then, is that the projection 


\section{SPECIFIC INDUSTRY OUTPUT}

\section{CHART I}

Frequency Distribution of Errors in Consumption-Model Projections, by Dollar Class Intervals

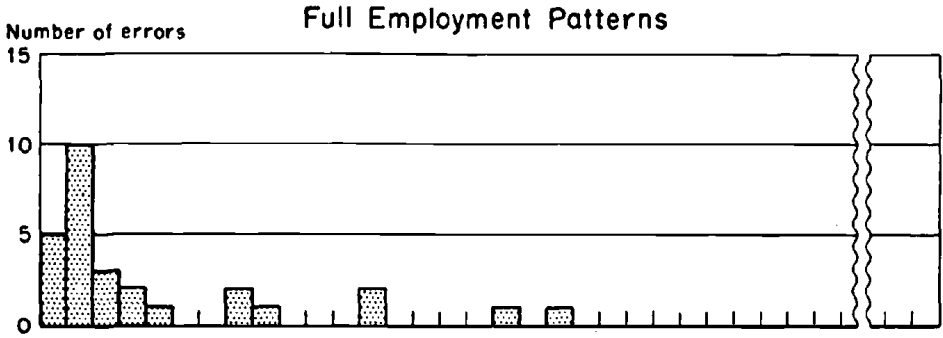

Multiple Regression

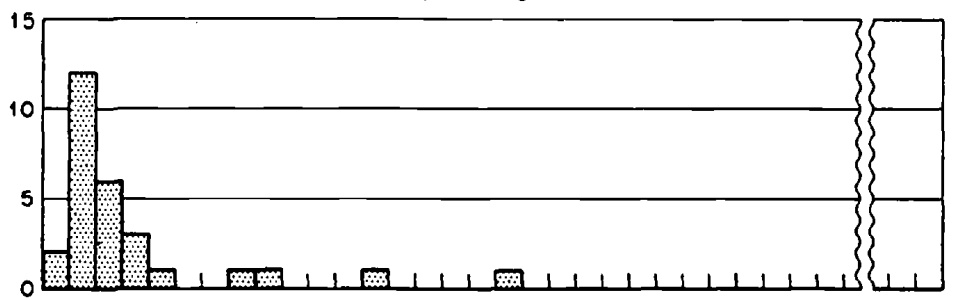

Final Demand Blowup

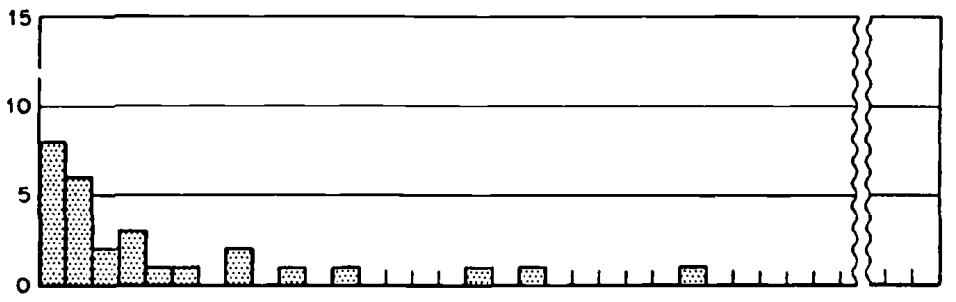

GNP Blowup

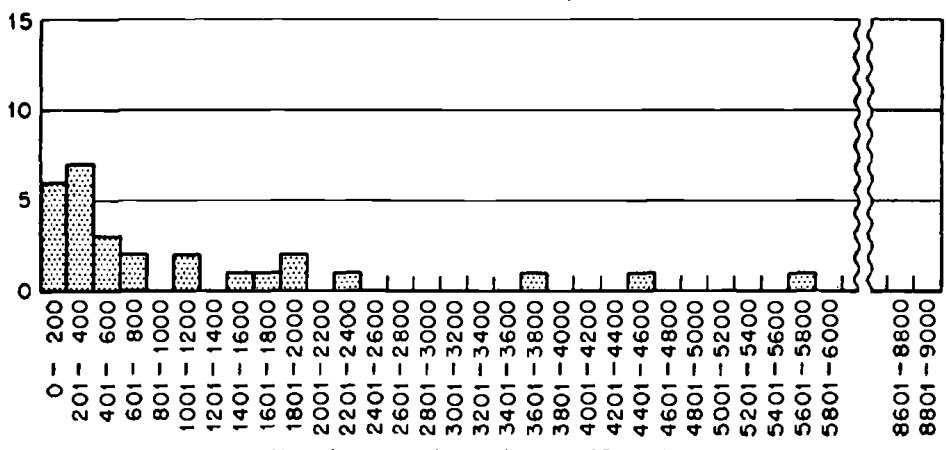

Source: Table 3. 
SPECIFIC INDUSTRY OUTPUT

CHART 2

Frequency Distribution of Errors in Investment-Model Projections, by Dollar Class Intervals

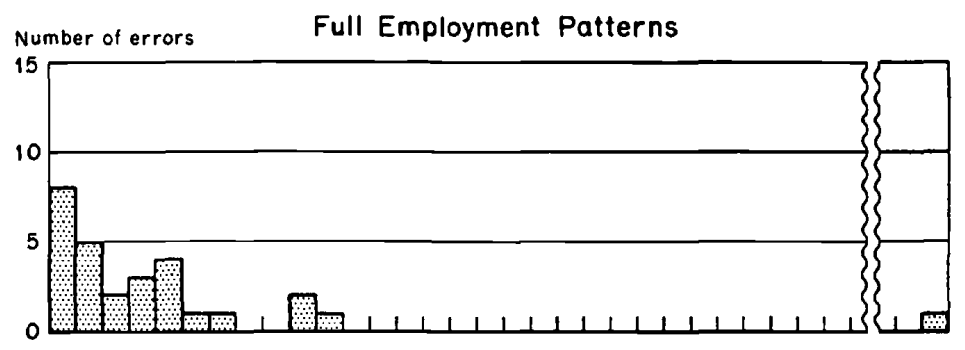

Multiple Regression

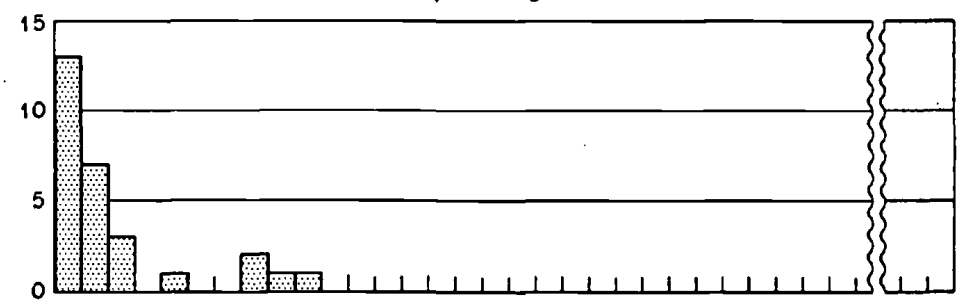

Final Demand Blowup

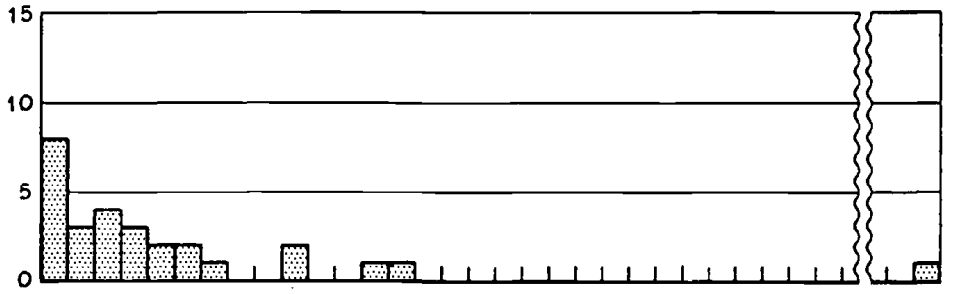

GNP Blowup

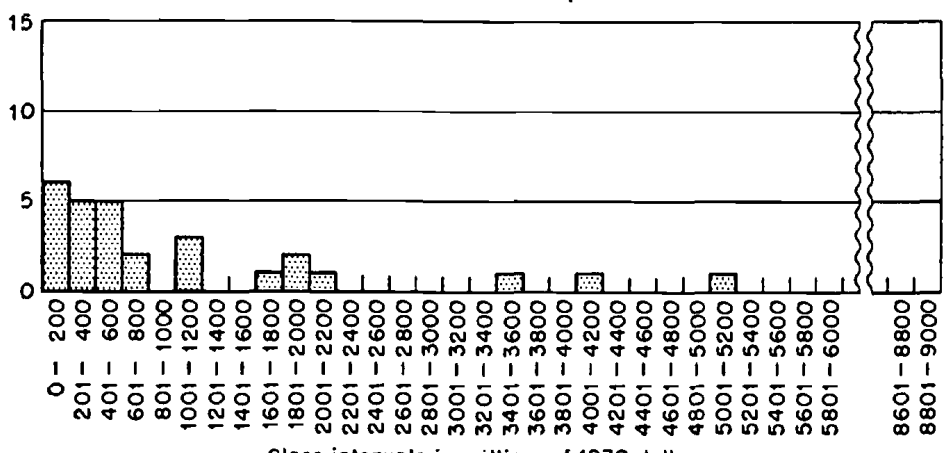
class intervals in millions of 1939 dollars

Source: Table 3. 


\section{SPECIFIC INDUSTRY OUTPUT}

CHART 3

Frequency Distribution of Errors in

Consumption-Model Projections, by Index Points

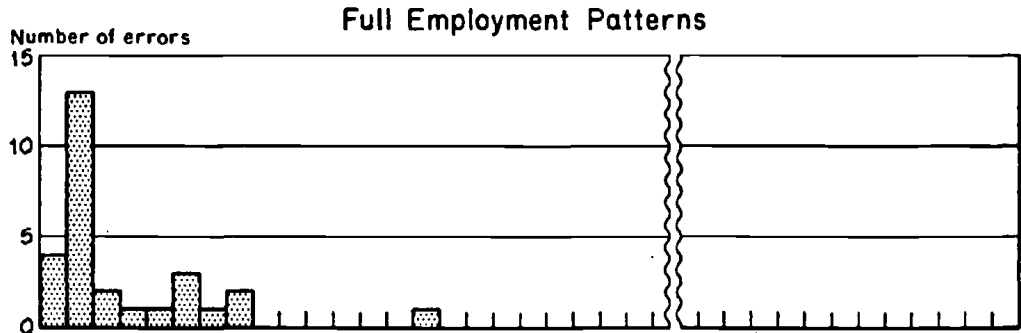

Multiple Regression

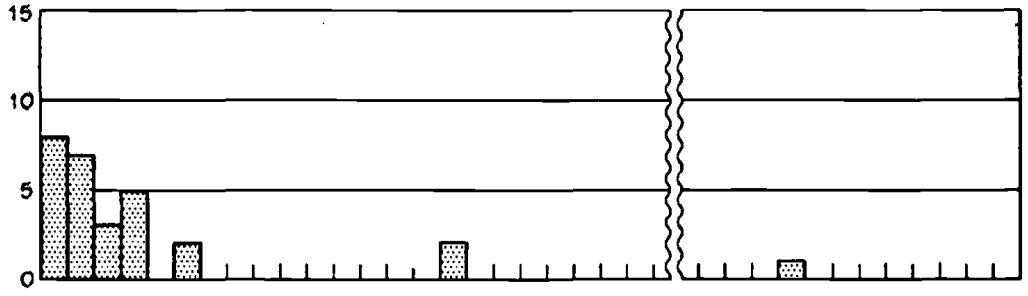

Final Demand Blowup

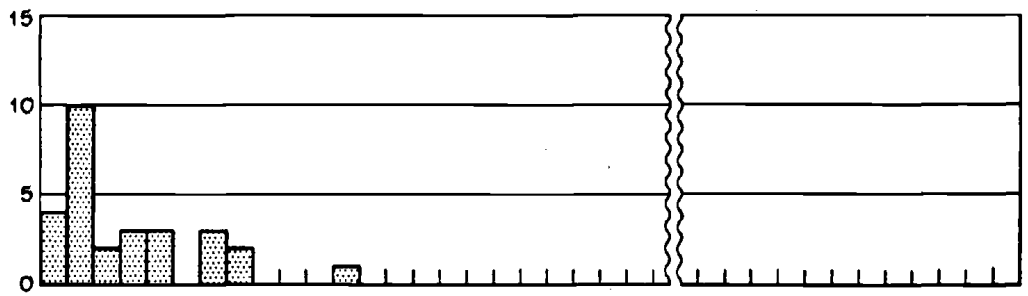

GNP Blowup

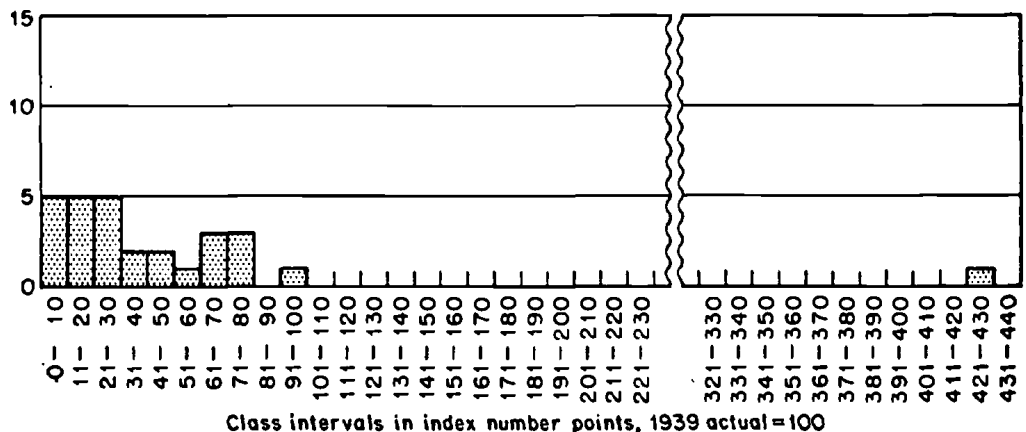

Source: Table 4. 
SPECIFIC INDUSTRY OUTPUT

\section{CHART 4}

Frequency Distribution of Errors in Investment-Model Projections, by Index Points

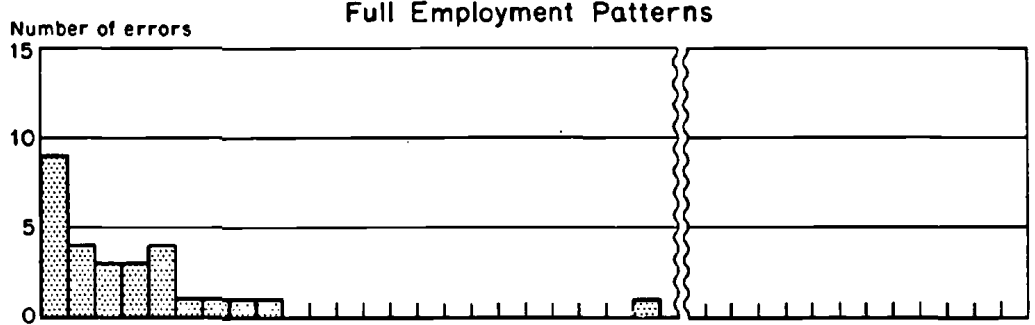

Multiple Regression

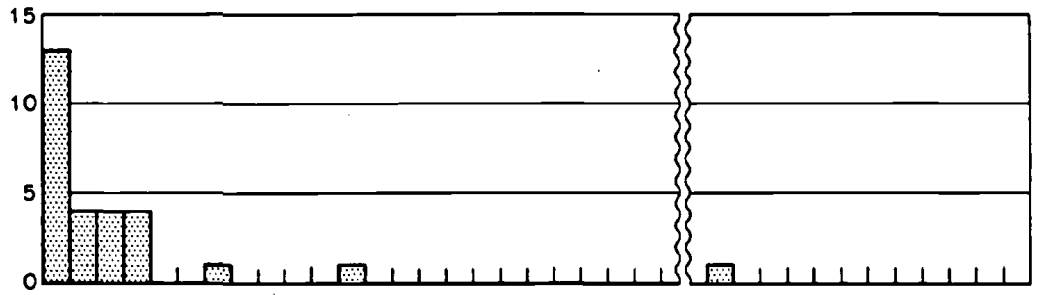

Final Demand Blowup

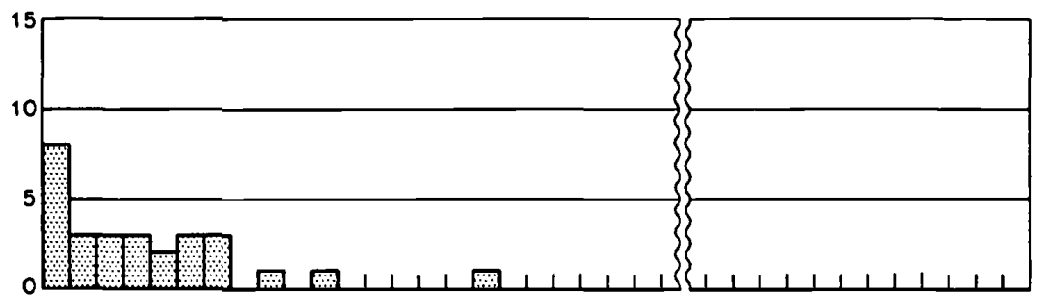

GNP Blowup

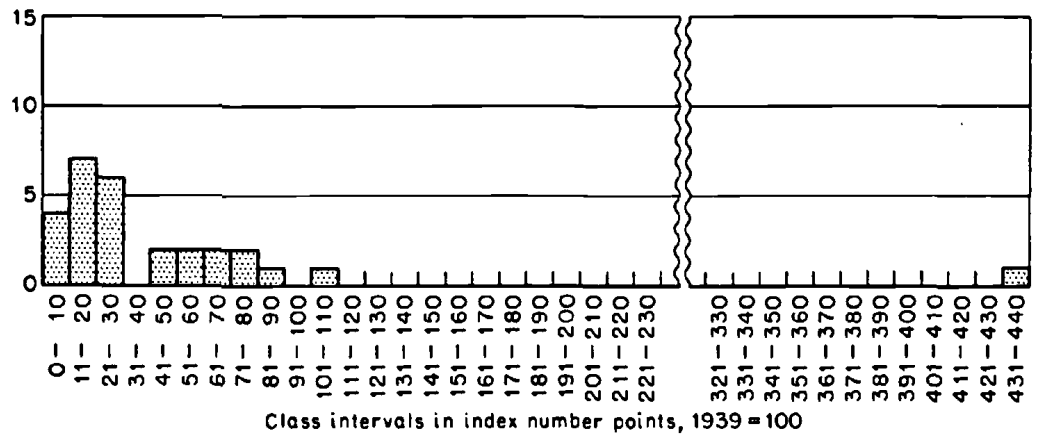

Source: Table 4. 
SPECIFIC INDUSTRY OUTPUT

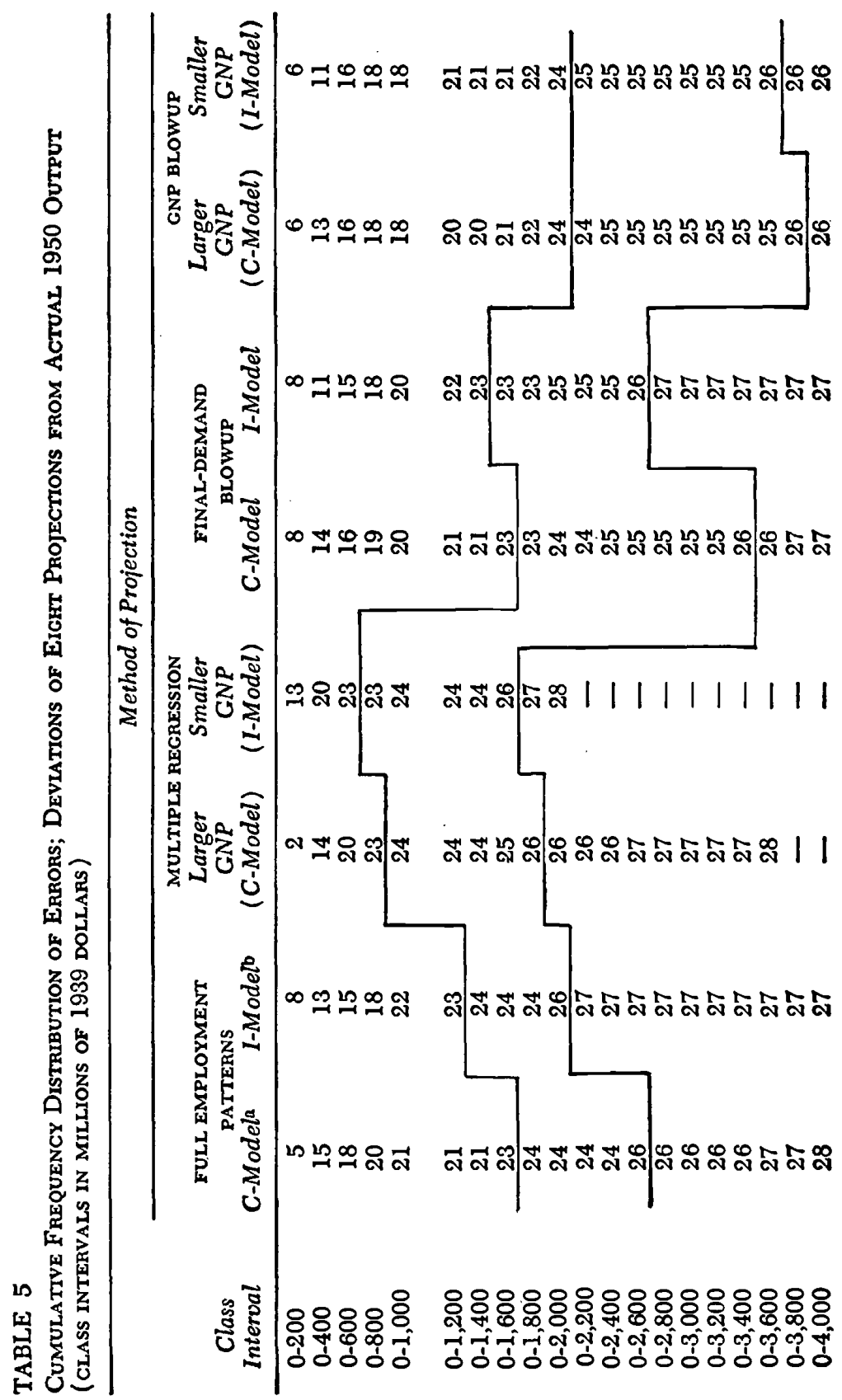


SPECIFIC INDUSTRY OUTPUT

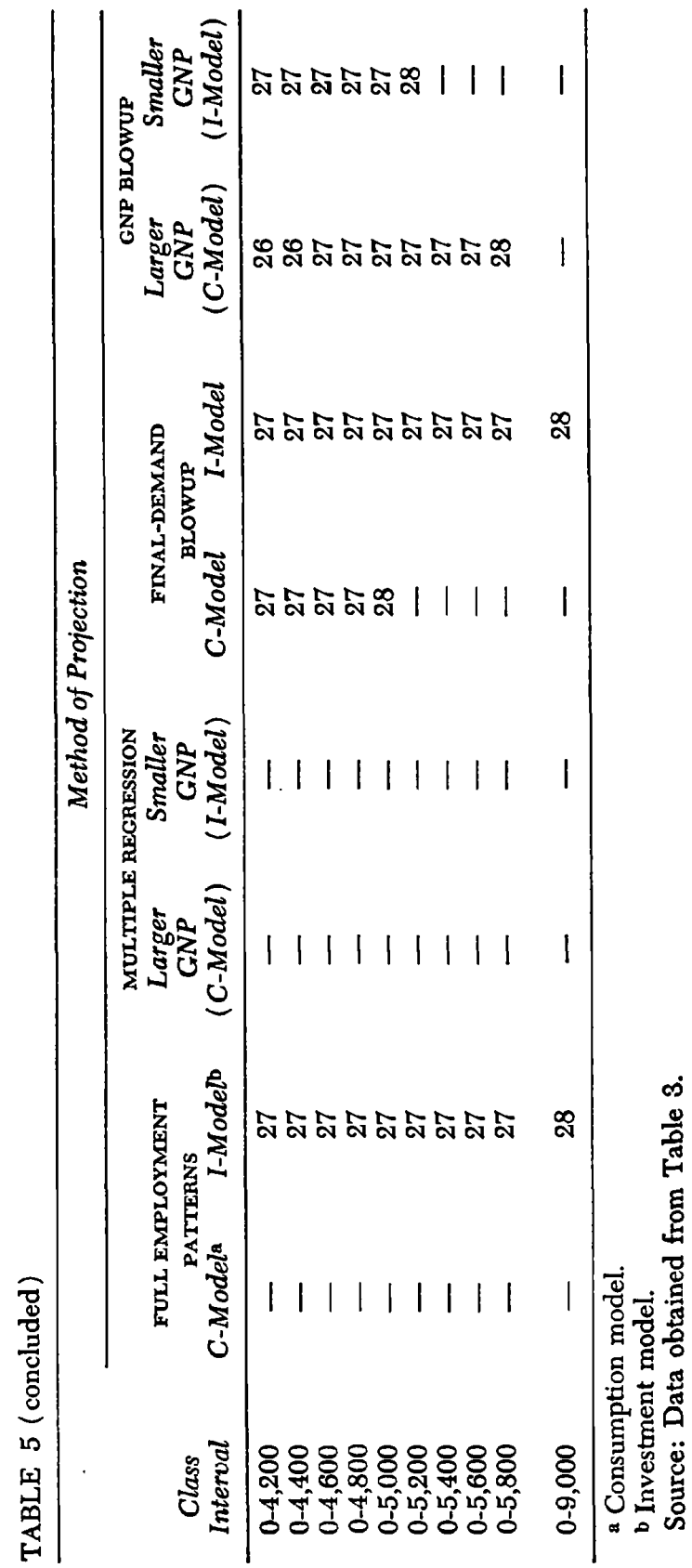


SPECIFIC INDUSTRY OUTPUT

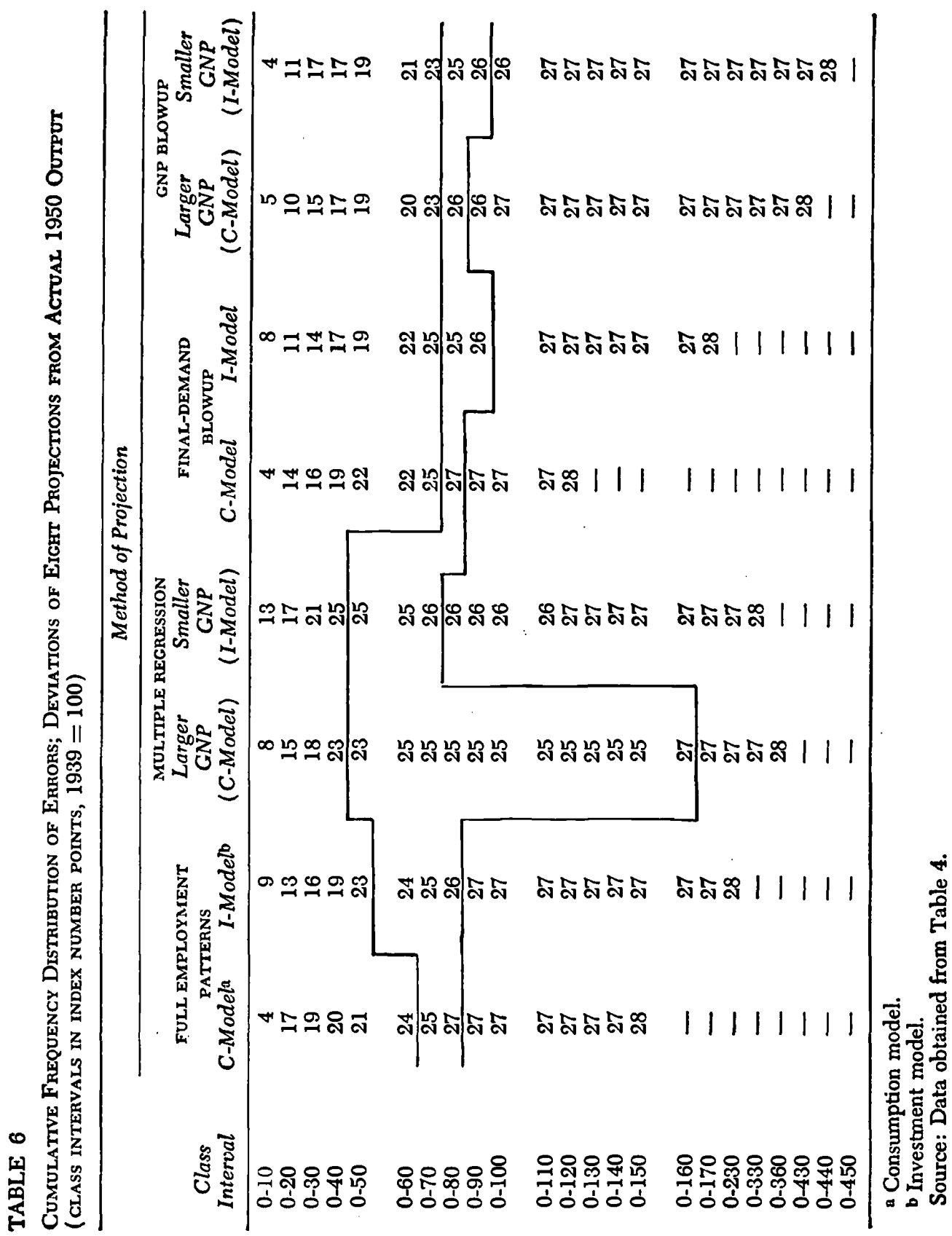




\section{SPECIFIC INDUSTRY OUTPUT}

errors depend on the handling of the ever present index number problem. ${ }^{7}$ And the second is that the constraint of the inputoutput-matrix industry classifications was in some cases unkind to regression analysis, which had to combine value weights with heterogeneous physical units which were individually well adapted to correlation analysis and projection (e.g., kilowatthours for electricity and British thermal units for manufactured gas). Full Employment Patterns, 1950 did not directly project commodity outputs in conventional physical units, which regression analysis normally does, and it is relevant that interest in specific industry outputs frequently centers on particular commodities.

A third qualification, related to the above two, is that I did not find it possible to apply the alternative techniques to some of the specific industries covered by the Bureau of Labor Statistics, for lack of output measures from which to determine actual 1950 output in relation to 1939. The deleted industries are trade, business and personal services, eating and drinking places, miscellaneous transportation, and iron and steel foundry products. In addition, I found it necessary to combine five BLS machinery categories (engines and turbines; industrial and heating equipment, n.e.c.; machine tools; merchandising and service machines; and electrical equipment, n.e.c.) in order to approximate the single machinery index of the Federal Reserve Board.

A fourth qualification is that the comparisons cannot be interpreted as generalized evaluations of alternative projection techniques for obvious reasons.

A fifth qualification is that the FEP estimates were not designed to project actual 1950:

"Neither of these models [consumption or investment] is in fact likely to be realized. If full employment is achieved in 1950, it is likely to be as a result of increases in all forms of demand. The

7 The authors of Full Employment Patterns, 1950 handled this problem in an arbitrary fashion (op.cit., table 16, p. 427). In most cases they appear to have assumed the percentage increases in their industry aggregations were representative of components of these aggregates. Thus they present the percentage increase in "Manufactured Gas and Electric Power" as the percentage increase applicable to kilowatt-hours; the percentage increase in "Agricultural Machinery" as the percentage increase applicable to tractors; the percentage increase in "Rubber" as the percentage increase in tires; etc. The unsatisfactoriness of this is indicated by the fact that this projects public utility electric power output for 1950 at about 245 billion kilowatt-hours, only 10 percent above 1944-46. 
two models thus provide extremes; a real full employment situation is likely to occupy an intermediate situation" (p. 421).

In this connection, however, the final-demand blowup projections utilized exactly the same extreme assumptions and resulted in mean errors approximately equal to those of Full Employment Patterns, 1950. This connotes that the specific inputoutput matrix used in the published article to calculate derived demand or intermediate output contributed little, in reducing error, to the conventional-type final-demand estimates on which the input-output matrix was hinged. This, however, is indirect and incomplete evidence of the validity of the underlying matrix used in these projections. More definitive evidence in the form of applying 1950's actual final demand is needed. I hope that Evans and Hoffenberg will make this test.

\section{RELATIVE ROLES OF FINAL DEMAND AND DERIVED DEMAND IN THE FULL EMPLOYMENT PATTERNS, 1950 PROJECTIONS}

I have had to attack the question of derived demand in an indirect fashion.

The differences between the investment-model specific industry projections and those of the consumption model are attributable to (1) sharply different conventional-type final-demand projections, and (2) calculations from a single input-output matrix of differences in derived demand, which stem wholly from the differences in the final-demand estimates. I ask this question: For each industry, what part of the difference between investmentmodel and consumption-model projections was accounted for directly by final-demand-estimate differences and what part stemmed indirectly from final-demand-estimate differences, in the form of input-output calculations of derived demand? The answers appear in Table 7.

It appears that the major part of the differences between investment-model and consumption-model industry projections resulted from the authors' conventionally estimated final-demand differences, and that a lesser part resulted from the input-output derived-demand shifts incident to the differing final demands. ${ }^{8}$

8 If construction final demand is visualized as final demand for cement, lumber, and steel, as it could be, then the derived-demand differences be- 


\section{SPECIFIC INDUSTRY OUTPUT}

\section{TABLE 7}

Differences by Industry between Two Models in Full Employment Patterns, 1950 Projections; Portion Accounted for by Final Demand and by Derived Demand ( IN INDEX NUMBER POINTS, $1939=100$ )

\begin{tabular}{|c|c|c|c|c|}
\hline Line & Industry & $\begin{array}{l}\text { Excess } \\
\text { of } 1950 \\
\text { C-Modela } \\
\text { over } 1950 \\
\text { I-Modelb } \\
\text { (1) }\end{array}$ & $\begin{array}{l}\text { Points } \\
\text { in Column I } \\
\text { Accounted } \\
\text { for by } \\
\text { Final Demand } \\
\text { (2) }\end{array}$ & $\begin{array}{c}\text { Points } \\
\text { in Column } 1 \\
\text { Accounted } \\
\text { for by } \\
\text { Derived Demand } \\
\text { (3) }\end{array}$ \\
\hline $\begin{array}{l}1 . \\
2 . \\
3 . \\
4 . \\
5 .\end{array}$ & $\begin{array}{l}\text { Agriculture and fishing } \\
\text { Food processing } \\
\text { Ferrous metals } \\
\text { Shipbuilding } \\
\text { Agricultural machinery }\end{array}$ & $\begin{array}{r}+20 \\
+26 \\
-43 \\
-8 \\
-88\end{array}$ & $\begin{array}{r}+6 \\
+18 \\
-3 \\
-16 \\
-86\end{array}$ & $\begin{array}{r}+14 \\
+8 \\
-40 \\
+8 \\
-2\end{array}$ \\
\hline $\begin{array}{r}6 . \\
7 . \\
8 . \\
9 . \\
10 .\end{array}$ & $\begin{array}{l}\text { Machinery } \\
\text { Motor vehicles } \\
\text { Aircraft } \\
\text { Transportation equipment, n.e.c. } \\
\text { Iron and steel, n.e.c. }\end{array}$ & $\begin{array}{r}-51 \\
-3 \\
-88 \\
-58 \\
-39\end{array}$ & $\begin{array}{r}-41 \\
-3 \\
-93 \\
-61 \\
-8\end{array}$ & $\begin{array}{r}-10 \\
0 \\
+5 \\
+3 \\
-31\end{array}$ \\
\hline $\begin{array}{l}11 . \\
12 . \\
13 . \\
14 . \\
15 .\end{array}$ & $\begin{array}{l}\text { Nonferrous metals and their products } \\
\text { Nonmetallic minerals and their products } \\
\text { Petroleum production and refining } \\
\text { Coal mining and manufactured solid fuel } \\
\text { Manufactured gas and electric power }\end{array}$ & $\begin{array}{r}-22 \\
-59 \\
+9 \\
-3 \\
+10\end{array}$ & $\begin{array}{r}-4 \\
0 \\
+11 \\
+3 \\
+10\end{array}$ & $\begin{array}{r}-18 \\
-59 \\
-2 \\
-6 \\
0\end{array}$ \\
\hline $\begin{array}{l}16 . \\
17 . \\
18 . \\
19 . \\
20 .\end{array}$ & $\begin{array}{l}\text { Communications } \\
\text { Chemicals } \\
\text { Lumber and timber products } \\
\text { Furniture and other wood manufactures } \\
\text { Wood pulp and paper }\end{array}$ & $\begin{array}{r}+15 \\
-6 \\
-62 \\
-11 \\
+7\end{array}$ & $\begin{array}{r}+15 \\
+2 \\
-2 \\
-9 \\
-2\end{array}$ & $\begin{array}{r}0 \\
-8 \\
-60 \\
-2 \\
+9\end{array}$ \\
\hline $\begin{array}{l}21 . \\
22 . \\
23 . \\
\\
24 . \\
25 .\end{array}$ & $\begin{array}{l}\text { Printing and publishing } \\
\text { Textile mill products } \\
\text { Apparel and other finished } \\
\text { textile products } \\
\text { Leather and leather products } \\
\text { Rubber }\end{array}$ & $\begin{array}{r}+22 \\
+17 \\
+32 \\
+23 \\
-3\end{array}$ & $\begin{array}{r}+7 \\
+1 \\
+31 \\
+17 \\
-3\end{array}$ & $\begin{array}{r}+15 \\
+16 \\
+1 \\
+6 \\
0\end{array}$ \\
\hline $\begin{array}{l}26 . \\
27 . \\
28\end{array}$ & $\begin{array}{l}\text { All other manufacturing } \\
\text { Construction } \\
\text { Steam railroad transportation } \\
\text { Total, ignoring signs } \\
\text { Columns } 2 \text { and } 3 \text { as percent of total }\end{array}$ & $\begin{array}{r}+13 \\
-103 \\
+4 \\
845\end{array}$ & $\begin{array}{r}+5 \\
-103 \\
+10 \\
570 \\
63\end{array}$ & $\begin{array}{r}+8 \\
0 \\
-6 \\
337 \\
37\end{array}$ \\
\hline
\end{tabular}

a Consumption model.

b Investment model.

c This total is less than the sum of columns 2 and 3 because of offsets in some cases; see, e.g., industry 4 , shipbuilding.

Sources: Column 1 was obtained from the Full Employment Patterns, 1950 projection columns, Table 2.

Column 2 was obtained by subtracting the 1950 final-demand estimate for the investment model from the 1950 final-demand estimate for the consumption model, and expressing the result as a percentage of 1939 total output. See Table A-3.

Column 3 was obtained by subtracting column 2 from column 1 . 
Derived demand from this matrix appears to be less responsive to final-demand variations than I expected. Evans and Hoffenberg have suggested that the matrix used was probably defective in terms of too large an "unallocated sector" (in the neighborhood of 25 percent of output) and too aggregative a set of industry classifications.

\section{E. CRUCIAL IMPORTANCE \\ OF FINAL DEMAND IN SPECIFIC INDUSTRY PROJECTIONS}

Let us conceive of industry projections of, say, 10 or 15 years' distance as involving a quantitative determination of how much greater or smaller the increase of an industry's output is than the projected (assumed) change in gross national product.

The Full Employment Patterns, 1950 approach breaks this determination into two stages: (1) a conventional-type estimate of how much industry output for final demand shifts relative to gross national product; (2) an input-output-matrix estimate of how much intermediate output-demand derived from the finaldemand estimates-shifts relative to gross national product. The final-demand estimates thư crucially enter both stages of the projections. They are not only large values in themselves in the first element, but they are also the axes on which derived demand turns. Error in final demand directly contributes error to the projections, and, through the input-output matrix, additional error in the derived-demand calculations.

In this situation it seems to me that it is probably at least as important to answer the questions-How valid are final-demand projections? What specific tendencies toward error do they have? What can be done to improve them? What is being done to improve them?-as to ask these questions about the input-output matrix. While I have not followed the recent literature carefully, my impression is that these final-demand questions have been relatively neglected; and it is possible that more attention to them might be at least as helpful in the problem of final-demand projections by industries as were earlier discussions and measurements in the related consumption function controversy.

tween the consumption and investment models become even less. As indicated in Table 7 , these construction commodities are the ones for which derived-demand outputs differ very sharply from one model to the other. 


\section{SPECIFIC INDUSTRY OUTPUTT}

In summary, an input-output table is a strenuous and detailed analysis of production functions. It is possible that we need to know a great deal more about analogous detailed consumption (final-demand) functions.

In comparison with the Full Employment Patterns, 1950 approach, a regression analysis of the type used earlier attacks the problem of industry output change relative to change in gross national product without the two-stage operation indicated above. It simply assumes that future total industry output will change relative to gross national product as it has in the past.

It is quite obvious that there is no a priori basis for knowing which type of projections will turn out to be more accurate in a specific case. The answer depends on the practical matter of data availability for each estimating approach. ${ }^{\theta}$ And since data and classifications are not of uniform quality for various industries and products, the answer depends also on which industries or products are being considered.

\section{APPENDIX}

\section{Notes to Table 2}

Actual output, 1950 is expressed as an index number, with $1939=100$. The source of this 1950:1939 ratio is, in most cases, the series shown in Table A-2. In six cases different series were used, for the reasons indicated below:

Industry
Agricultural machinery
Petroleum production
and refining

Manufactured gas and electric power

Communications

\section{Series and Source Used for 1950 Index}

The ratio of 1949 to 1939 total domestic shipments of wheel-type tractors (Table 628 in the 1950 Agricultural Statistics) was used because census data on farm equipment were not available. $M$. Hoffenberg of the Bureau of Labor Statistics suggested this alternative as a satisfactory approximation of a farm equipment 1950:1939 ratio.

I used the Federal Reserve Board petroleum production series in error instead of a production and refining series. These series, which moved together in pre-war years, have diverged since the war. The correct 1950:1939 ratio is 160 , as compared with the $156 \mathrm{I}$ show in Table 2.

I used the series prepared by the Council of Economic Advisers. See the Annual Economic Review, 1951, p. 186.

I used the CEA series for the production of telephone and telegraph services. The source does not

${ }^{9}$ As indicated, I suspect that difficulties in estimating final demand for a free enterprise peacetime economy constitute an important obstacle to the Full Employment Patterns, 1950 approach for such an economy. 


\section{SPECIFIC INDUSTRY OUTPUT}

Industry

Construction

Steam railroad transportation

\section{Series and Source Used for 1950 Index}

show 1950 production, which I estimated by increasing 1949 production by $2 \frac{1}{2}$ percent, the increase from 1948 to 1949 . This increase is less than the increase in number of telephones but more than the increase in the number of workers employed in telephone and telegraph industries as shown in the 1951 Survey of Current Business. I preferred the CEA series to my makeshift "number of telephones" series.

I used the CEA series, which I preferred to my own series.

I used the CEA series on transportation services, which I preferred to the Interstate Commerce Commission series.

The actual gross national product for 1950 is in 1939 dollars (page 179 of the CEA document referred to above) converted to the base $1939=100$.

Full employment patterns projections are from J. Cornfield, W. Evans, and M. Hoffenberg, Full Employment Patterns, 1950 (Government Printing Office, 1947). They may be read directly from Table 15, except in the case of the machinery industry, which comprises five FEP classifications.

Multiple regression projections are based on historical regressions calculated in the Rand computing laboratory, as indicated in the correspondence quoted in part below:

Mr. Ronald W. Shephard

Economics Division

Rand Corporation

Herewith the series (Table A-2 below). You'll remember the problem is to correlate each of the series with GNP and time. The forms of the functions should be simple-either output $=A$ plus $(\mathrm{GNP})$ plus $C$ (time) or output $=a \cdot b^{\mathrm{GNP}} \cdot c^{\mathrm{t} \mid \mathrm{m} \bullet}$, whichever would appear to be the better fit. If the better fit cannot be determined by inspection, then let them all be fitted by the latter equation. If the latter equation adds substantially to the work, then let them all be fitted by the former equation, except that I will note that there is considerable usefulness in observing the time drift as a constant rate. Please don't bother with lagging any of the variables-in some cases it is a component of GNP that is the proper independent variable, and I haven't introduced this more important improvement. You'll remember that one of the important elements of the test is that it be quite mechanical in order that there be no question of hindsight.

Harold J. Barnett

Mr. Harold J. Barnett

3417 Pendleton Drive

Wheaton, Maryland

I enclose herewith your original data sheets [Table A-2] and a summary of the correlation calculations [Table $A-1$ ]. The regression $Y=\bar{A} \cdot \bar{B}$ aNP $\cdot \bar{C}$ "lme is written in logarithmic terms as $\log Y=$ $A+B$ GNP $+C$ time, where $A=\log \bar{A}, B=\log \bar{B}, C=\log \bar{C}$. But the corresponding standard errors of estimate [(Se) log. est] and correlation coefficients [C.C. log. est] are computed in absolute terms, 


\section{SPECIFIC INDUSTRY OUTPUT}

that is, in terms of the residuals about the nonlog regression $Y=$ $\bar{A} \cdot \bar{B}^{\text {oNP }} \bar{C}^{\text {ime }}$. The coefficients for both regressions (linear for arithmetic $Y$ and linear for $\log Y$ ) are given, with $D, E, F$ referring to the straight arithmetic regressions-as indicated in the upper left hand corner of the attached sheet. The coefficients $\bar{A}, \bar{B}, \bar{C}$, of the exponential regression (log. est) are found as anti-logs of $A, B, C$, respectively.

A word about the equation $Y=D+E$ (GNP) $+F$ (time). The origin of time for this equation is the year 1934, the unit of time is one year, and time is measured positively going forward from 1934 and negatively going backward from 1934. The year 1950 would correspond to a value of $T$ equal to +16 .

\section{Ronald W. Shephard}

The linear relationship $Y=D+E$ (GNP) $F$ (time), which fitted better in most cases, was chosen for the projections for all industries.

The multiple regression projections were computed by taking $T$ (time) $=$ 16 , GNP (gross national product) $=170$ for the consumption model, GNP $=163$ for the investment model, and by using the appropriate values of $D, E$, and $F$ for each industry, as given in Table A-1. The results were then converted, where necessary, to the base $1939=100$. The GNP figures are in billions of dollars. They were obtained by applying the 1939 percentages furnished by Marvin Hoffenberg, 186 and 179, respectively, to the 1939 actual gross national product of $\$ 91.3$ billion.

The time series used in the regressions are presented in Table A-2. The correlation period $1922-41,1946$ was used. A few years were omitted because time series data were not available.

Certain 1950 values have been added. These values were not part of the original data series sent to Rand and referred to in the correspondence quoted above.

Final-Demand Blowups. The source of the changes in final demand from (actual) 1939 to (estimated) 1950 is Full Employment Patterns, 1950, table 14, p. 34 . The blowups may be read directly from this table, except for the machinery industry, which comprises five FEP classifications. 
SPECIFIC INDUSTRY OUTPUT

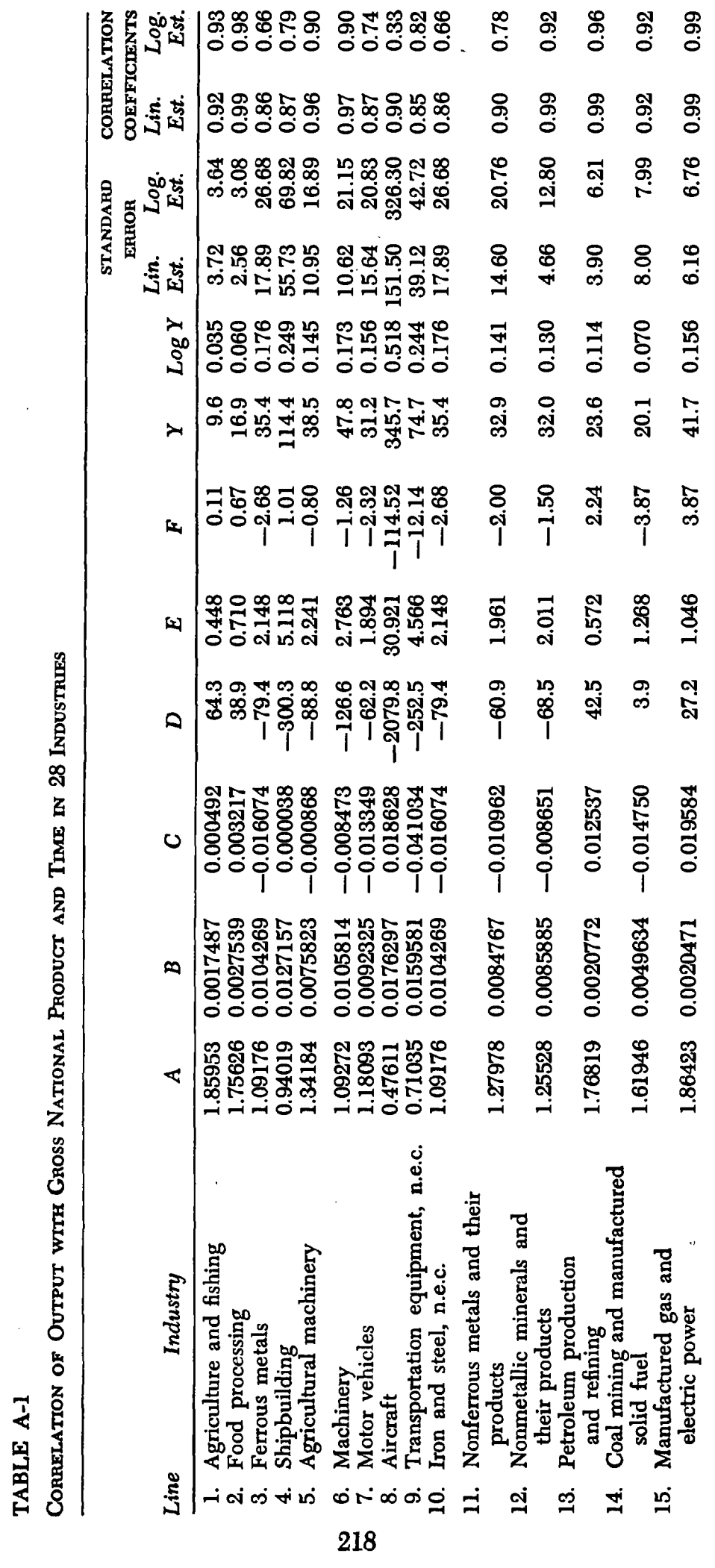


SPECIFIC INDUSTRY OUTPUT

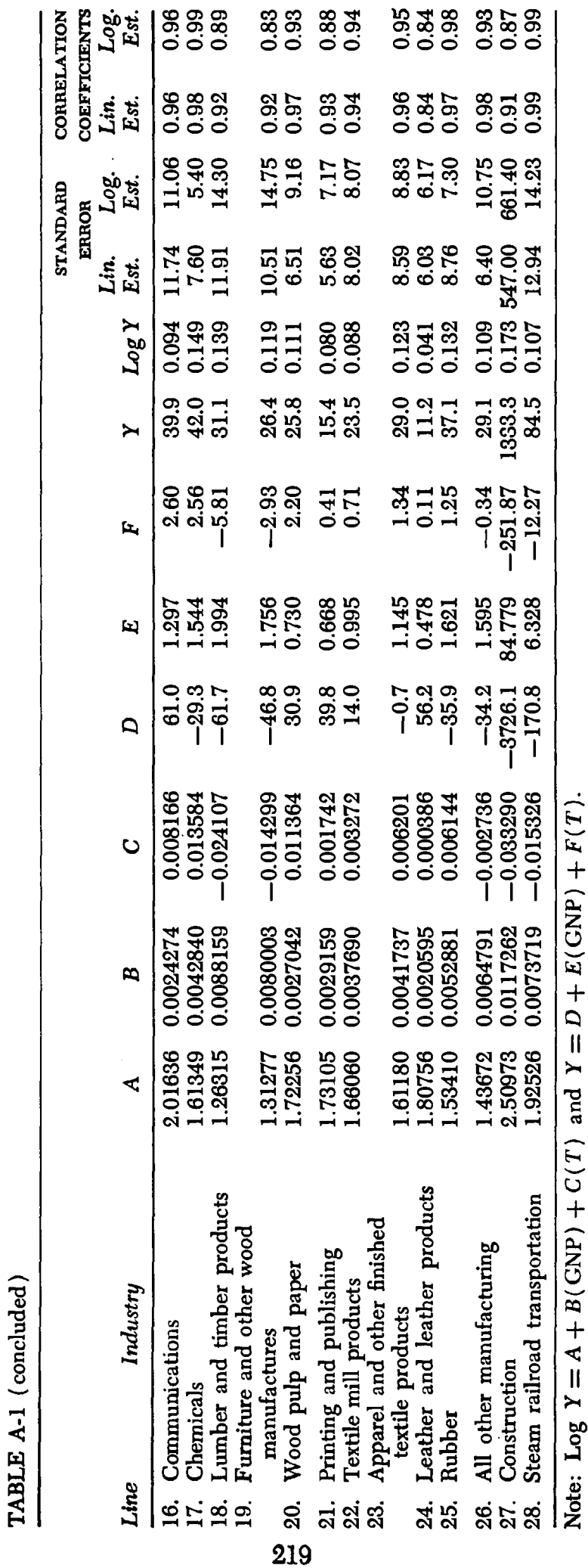


SPECIFIC INDUSTRY OUTPUT

t5

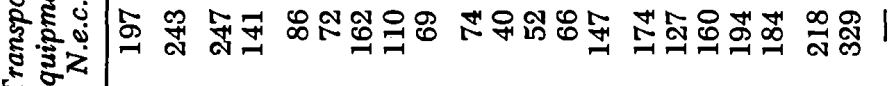

सा:

赵

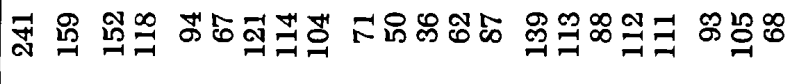

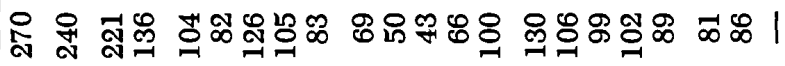

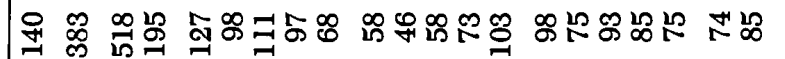

$\stackrel{8}{8}$

$\vec{t} \rightarrow \widehat{8}$

胥

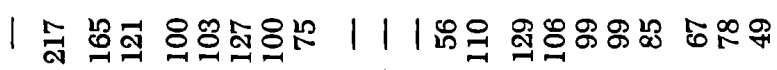
क्ष

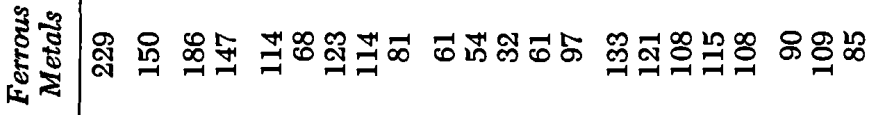

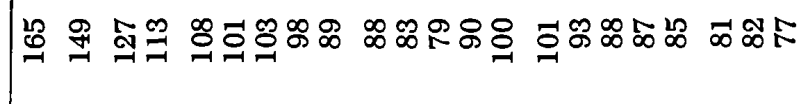

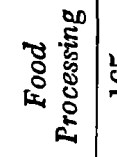

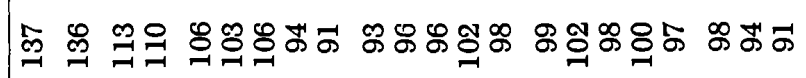
ธิ

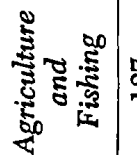

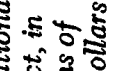

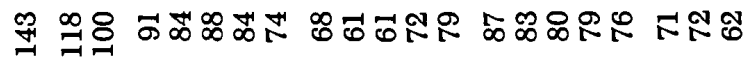

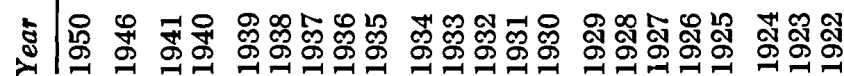


SPECIFIC INDUSTRY OUTPUT

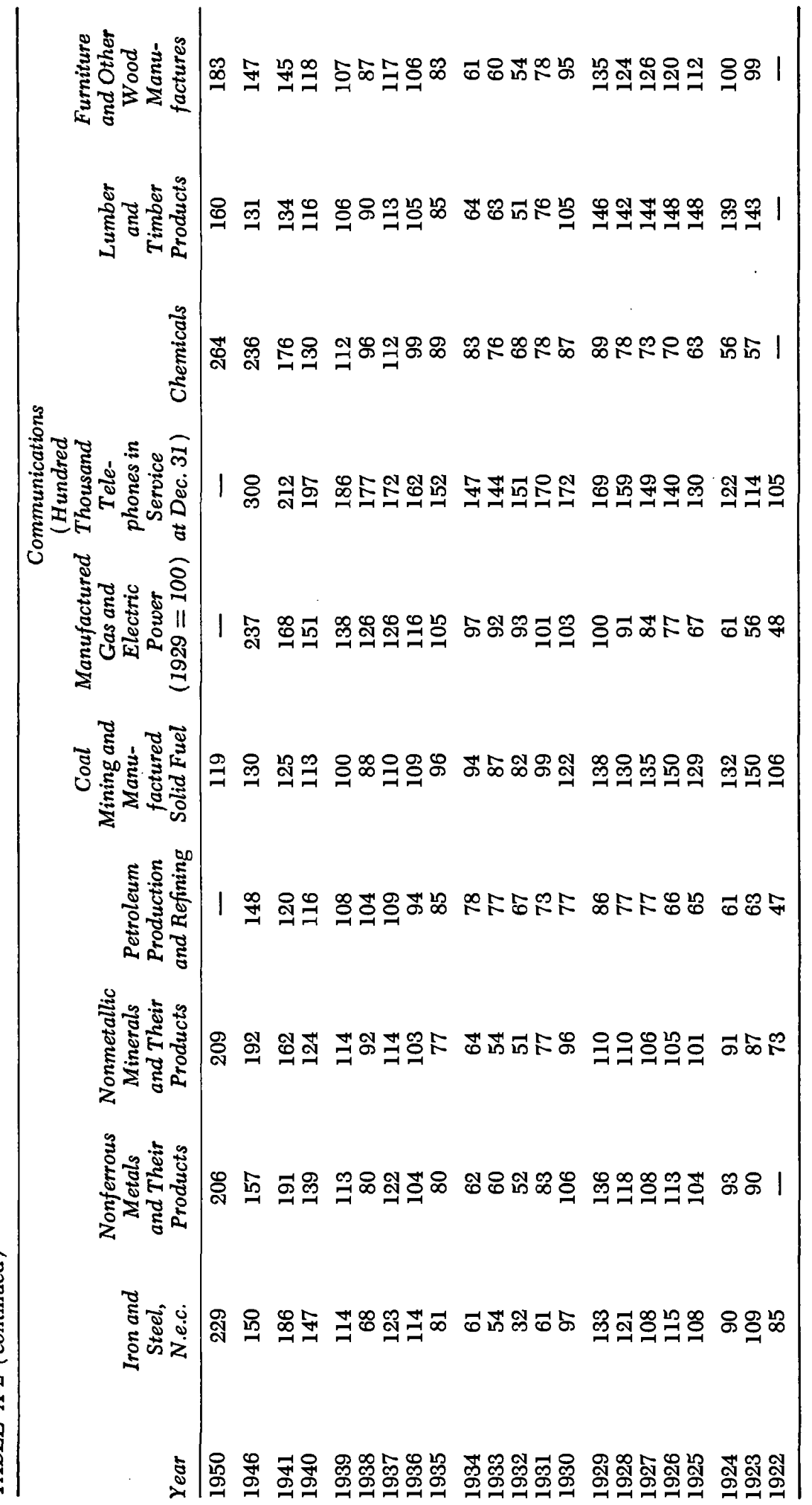




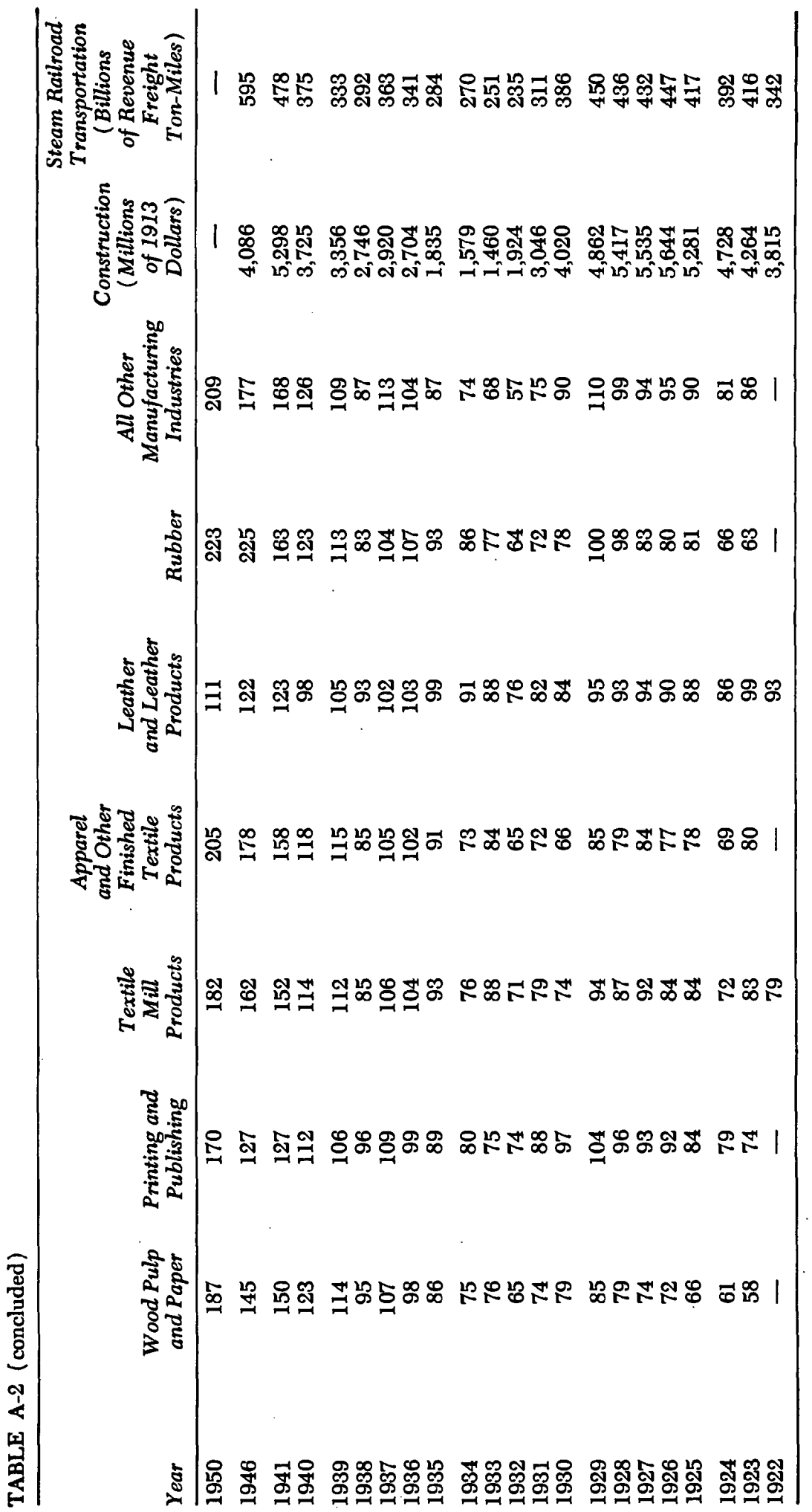




\section{SPECIFIC INDUSTRY OUTPUT}

\section{Notes to Table A-2}

Gross national product. That used in Table A-2 is my deflation of published current-dollar gross national product data of the U.S. Department of Commerce and of Simon Kuznets, National Bureau of Economic Research. The official Department of Commerce gross national product series in 1939 dollars was first published in January 1951, and was not available for use when the regressions were computed. It differs somewhat from the gross national product series used in this paper, as indicated below. Both gross national product series are shown, in billions of 1939 dollars.

$\begin{array}{ccc}\text { Year } & \begin{array}{c}\text { Department of } \\ \text { Commerce Series }\end{array} & \begin{array}{c}\text { Barnett } \\ \text { Series }\end{array} \\ 1929 & 86 & 87 \\ 1930 & 78 & 79 \\ 1931 & 72 & 72 \\ 1932 & 62 & 61 \\ 1933 & 62 & 61 \\ 1934 & 68 & 68 \\ 1935 & 74 & 74 \\ 1936 & 84 & 84 \\ 1937 & 88 & 88 \\ 1938 & 84 & 84 \\ 1939 & 91 & 91 \\ 1940 & 100 & 100 \\ 1941 & 116 & 118 \\ 1946 & 138 & 143\end{array}$

Production indexes. Those cited in the list below as being FRB indexes are from the Board of Governors of the Federal Reserve System and may be found in the following publications: for 1922-41, Federal Reserve Index of Industrial Production (Board of Governors of the Federal Reserve System, 1943 ); for 1946 and 1950, Industrial Production, by Industries, Annual Indexes (mimeographed release, Division of Research and Statistics, Federal Reserve System, 1951). There is no published source for the 1946 and 1950 FRB indexes for shipbuilding (private yards), aircraft, railroad cars, and locomotives. These indexes were kindly furnished by the Federal Reserve Board.

Item

1. Agriculture and fishing

2. Food processing

3. Ferrous metals

4. Shipbuilding

5. Agricultural machinery

\section{Source}

Department of Agriculture, "Index of Volume of Agricultural Production for Sale and for Consumption in the Farm Home, All Commodities," 1946 Agricultural Statistics, table 612; 1950 Agricultural Statistics, table 655; Annual Economic Review of the Council of Economic Advisers, January 1951, p. 186.

FRB index, "Manufactured Food Products."

FRB index, "Iron and Steel."

FRB index, "Shipbuilding (Private Yards)."

Department of Agriculture, reprocessed data of the Bureau of the Census on the value of manufacturers' shipments of farm machines and equipment. 1929-46 data from 1950 Agricultural Statistics, table 630, deflated by the Department of Agricul- 


\section{SPECIFIC INDUSTRY OUTPUT}

\section{Item}

5. Agricultural machinery (cont.)

6. Machinery

7. Motor vehicles

8. Aircraft

9. Transport equipment, n.e.c.

10. Iron and steel, n.e.c.

11. Nonferrous metals and their products

12. Nonmetallic minerals and their products

13. Petroleum production and refining

14. Coal mining and manufactured solid fuel

15. Manufactured gas and electric power

16. Communications

17. Chemicals

18. Lumber and timber products

19. Furniture and other wood manufactures

20. Wood pulp and paper

21. Printing and publishing

22. Textile mill products

23. Apparel and other finished textile products

24. Leather and leather products

25. Rubber

26. All other manufacturing

27. Construction

28. Steam railroad transportation

\section{Source}

ture farm machinery price index from ibid., table

677 , converted by author to base $1939=100$.

FRB index, "Machinery."

1922-34: FRB index, "Automobile Factory Sales." 1935-50: FRB index, "Automobile Bodies, Parts, and Assembly."

FRB index, "Aircraft."

FRB indexes, "Railroad Cars" and "Locomotives," weighted 4 and 1, respectively; computations by author.

FRB index, "Iron and Steel."

FRB index, "Nonferrous Metals and Products."

FRB index, "Stone, Clay, and Glass Products."

Survey of Current Business (Department of Commerce), "Crude Production" and "Crude Run to Stills," weighted 2 and 1 , respectively, by author on basis of values added by manufacturing as given in 1939 Census of Manufactures.

FRB index, "Bituminous Coal" and "Anthracite," weighted by author 4 and 1 , respectively.

J. M. Gould, Output and Productivity in the Electric Power and Gas Utilities, 1899-1942 (NBER, 1946). Extensions by the present author.

Survey of Current Business, "Hundreds of Thousands of Telephones in Service at December 31."

FRB index, "Chemical Products."

FRB index, "Lumber and Products."

FRB index, "Furniture."

FRB index, "Paper and Paper Products."

FRB index, "Printing and Publishing."

FRB index, "Textiles and Products."

Special components of the FRB textile group, weighted by value added in the respective apparel industries. Data furnished by the FRB.

FRB index, "Leather and Products."

FRB index, "Rubber Products."

FRB index, "Manufactures Total."

Total new construction in dollars deflated by the Associated General Contractors construction cost index. Both series in the Survey of Current Business. Computations by author.

Statistics of Railways in the United States, annual reports of the Interstate Commerce Commission. 
SPECIFIC INDUSTRY OUTPUT

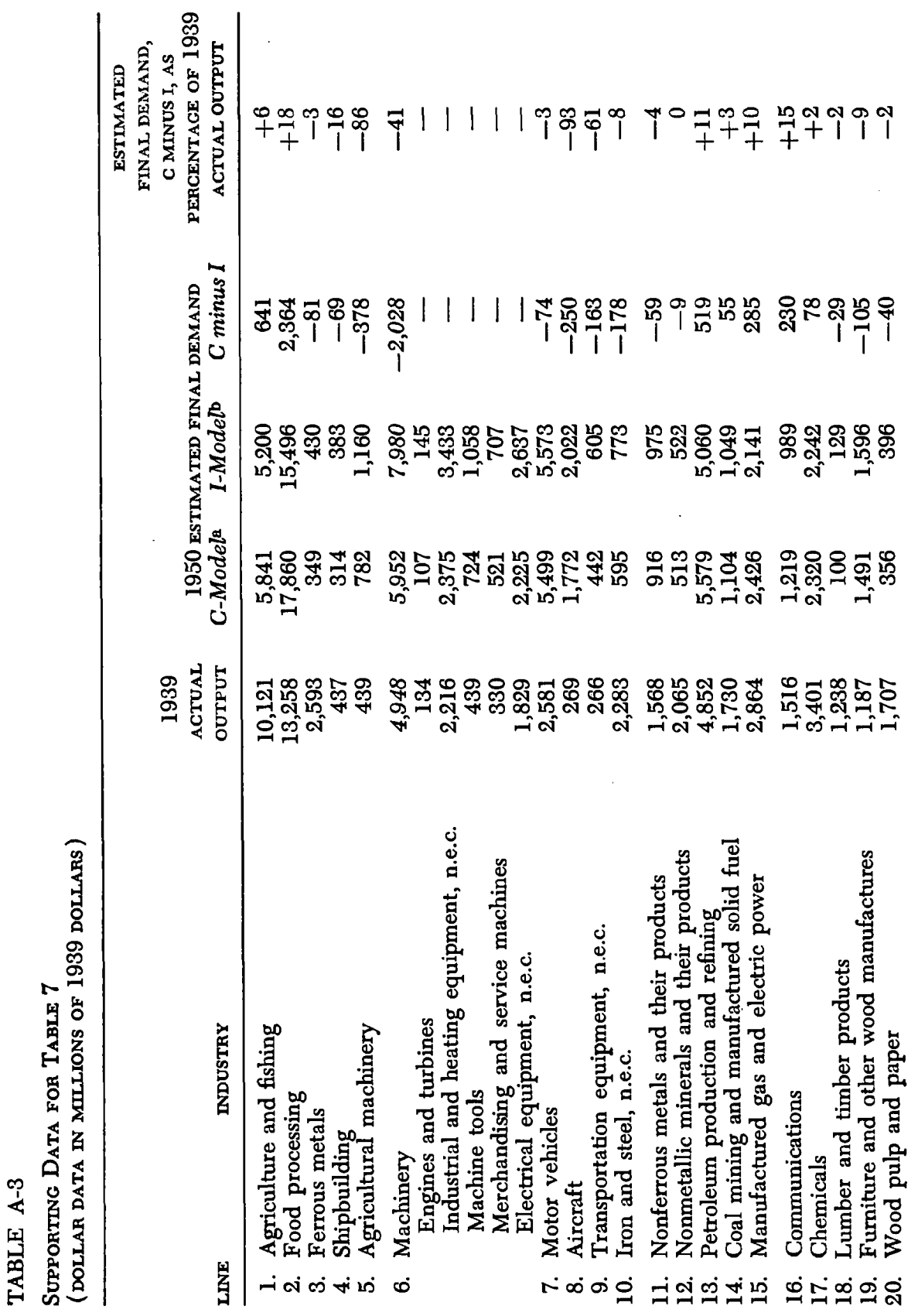


SPECIFIC INDUSTRY OUTPUT

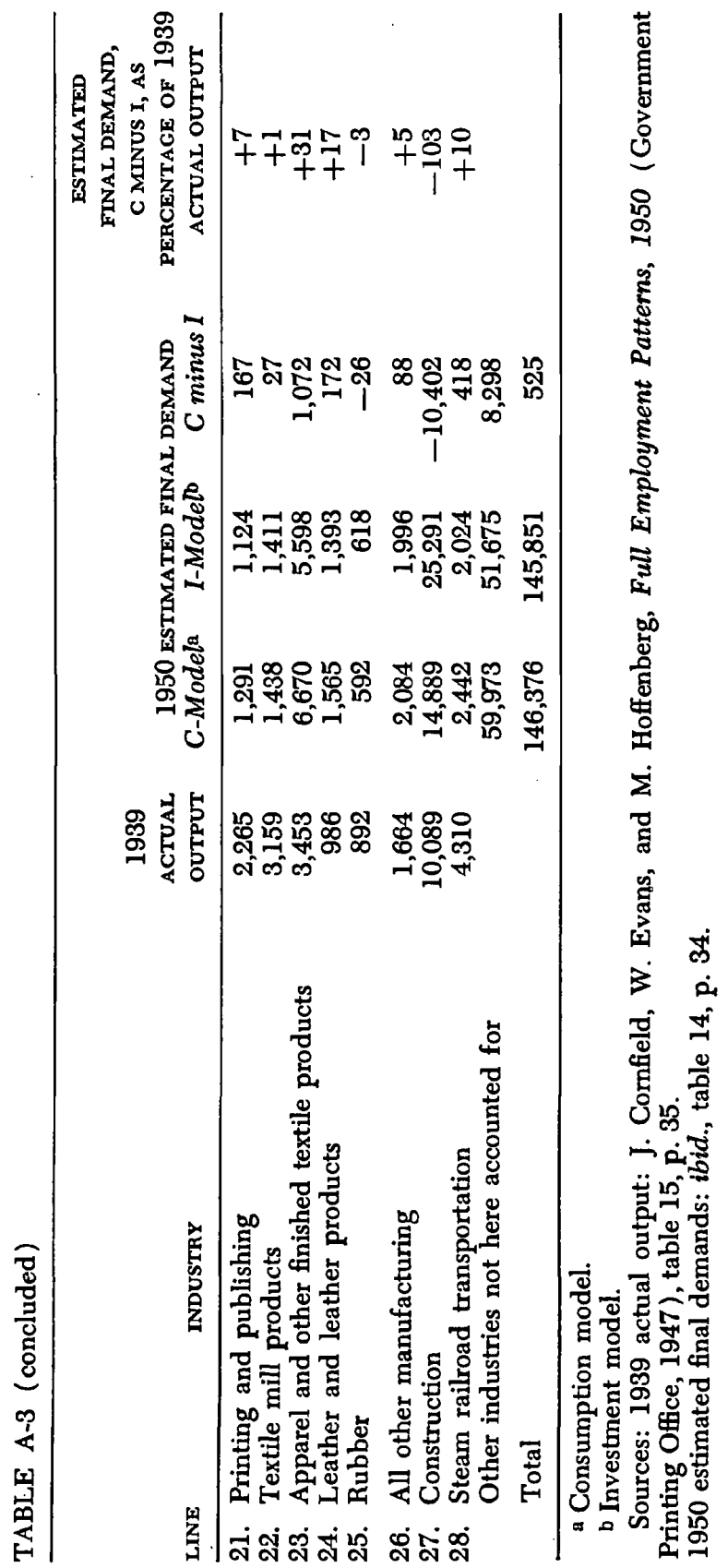




\section{A. W. Marshall, Rand Corporation}

Two comments arise with regard to Dr. Barnett's paper. The first concerns the appropriateness of comparisons made in the paper for decisions as to the acceptance or rejection of proposed forecasting methods. The second comment concerns a suggested alternative method of measuring the forecasting errors.

Given the comparisons in Tables 3 and 4 based upon the mean deviations of actual from predicted industry outputs, it appears that projection methods using input-output tables are not very much better than quite elementary "naive" model methods. Indeed, the multiple regression forecasts seem to be somewhat better than those based, in part, upon input-output relations. In situations such as this, where "naive" models have in some sense to be taken seriously (e.g., if asked to forecast output by industry for, say, 1956, I would prefer Barnett's multiple regression forecasts), it is well to keep in mind their purpose and character. They are not intended to be legitimate alternatives to the model or procedure being tested, but rather are designedly crude and inefficient things, almost reductio ad absurdum constructions of economic models and forecasting procedures. They represent a level of efficiency so low and so easily attained that any forecasting procedure proposed for operational use which cannot almost uniformly do better than they can must be rejected as unacceptable.

Two warnings are needed here. First, Barnett's multiple regression model must be conceded to be "seminaïve," in the sense that even if we were to add. additional variables to the equations which we felt had a special relevance for the output of some specific industry, it is unlikely, due to the correlation between most economic time series, that continued large reductions in the sum of squares about the regression line could be obtained. Second, the kinds of comparison made in Barnett's paper are very appropriate to decisions as to whether a certain method of forecasting should be used in practice, given its current stage of development, but are often of minor importance with regard to decisions concerning the advisability of continuing development of these methods. Thus, this type of competitive trial of serious, though perhaps immature, models and forecasting methods against "naïve" models should not lead anyone to discard, or 


\section{SPECIFIC INDUSTRY OUTPUT}

neglect the development of, really promising techniques.

I should also like to suggest an alternative and more natural, at least to a mathematician, measure of the error of prediction of the various methods of projecting or estimating specific industry outputs in some future year. In Tables 3 and 4, Barnett has used as his measure of error

$$
\sum_{i=1}^{28}\left|X_{i}\left(\mathrm{GNP}^{*}\right)-X_{i}(A)\right|
$$

where $X_{1}\left(G N P^{*}\right)$ denotes the estimated output, in terms of an index number of dollar value, of the $i$ th industry based upon the estimate GNP* of GNP, and $X_{i}(A)$ denotes the actual output of the $i$ th industry. All of the above, of course, refers to some fixed year and method of forecasting. As an alternative, it is appealing to think of the observed production by industry and the projected productions as vectors in $n$-dimensional Euclidean space, and to think of the error of the projection as being the distance between the two points. Each vector then has 28 components and the distance between the two points (vectors) is

$$
d=\left\{\sum_{i=1}^{28}\left[X_{i}\left(G N N P^{*}\right)-X_{i}(A)\right]^{2}\right\}^{\frac{1}{2}}
$$

Not only is this the more usual definition of the distance between two vectors, but it is also a measure which fits in with what would seem to be, from the statistical point of view, the aim of research in forecasting methods, i.e., the finding of minimum variance estimates of the future values of economic variables. From this point of view, once we decide what to forecast, all questions of further disaggregation resolve themselves into questions as to whether a particular disaggregation reduces the variance of our forecasts.

One additional comment may be made. Since it seems to be almost certain that, in the future, we will have estimates of GNP which have considerably smaller errors than the estimates used in the present paper, some separation of the total error of the various forecasting techniques into its component parts is desirable. Errors of the order of magnitude made in the GNP estimates are so bad that none of the methods obtained a fair trial in an absolute sense. It is in general desirable to be able to factor out the errors contributed by the separate steps in the forecasting methods, since one method may be much more sensitive than another to errors in some common component, say, the first com- 
ponent in all of the forecasting methods in Barnett's paper, the estimate of GNP. This factorization is easily carried out in principle as follows: Let us denote by $X_{i}$ (GNP) the estimated output of the $i$ th industry, which we would have made if we had known the true value of GNP. Then we have

$$
d_{1}=\left\{\sum_{i=1}^{28}\left[X_{i}(\mathrm{GNP})-X_{i}(A)\right]^{2}\right\}^{\frac{1}{2}}
$$

as a measure of the error we would have made, even if we had had the best possible knowledge of the value of GNP. Also, we have

$$
d_{2}=\left\{\sum_{i=1}^{28}\left[X_{i}\left(\mathrm{GNP}^{*}\right)-X_{i}(\mathrm{GNP})\right]^{2}\right\}^{\frac{1}{2}}
$$

and thus the total error $d$ is separated into two factors of which it is the vector resultant.

As an example, I have performed this factorization for Barnett's multiple regression method, where one can easily obtain the $X_{i}$ (GNP) from the equation

$$
X_{i}(\mathrm{GNP})=a_{i}+b_{i} \mathrm{GNP}+c_{i} t
$$

by substituting the correct value of GNP rather than the estimate GNP $^{*}$ used to obtain the values in Barnett's Tables 3 and 4. To do a similar factorization for the input-output method would entail much more work. Working with the consumption model $\left(\mathrm{GNP}^{\circ}=170,000\right)$ and the dollar value figures in millions of 1939 dollars, we obtain these components of error:

Error Components

$d$ (total error)

$d_{1}$ (error, given exact

GNP estimate)

$d_{2}\left(\mathrm{GNP}^{*}\right.$ component of error)
Multiple Regression

5,325

3,354

6,052

Input-Output 7,178

Thus, using an estimate of GNP which is too large by 11.5 percent leads to an over-all increase in the error of forecast of 59.0 percent. The reader will also notice that the distance between the two estimates, one based upon GNP and the other upon $\mathrm{GNP}^{\circ}$, is greater than the distance of each estimate from the true value. If we were concerned with a two-industry world, this situation could be depicted as in Chart 1. 


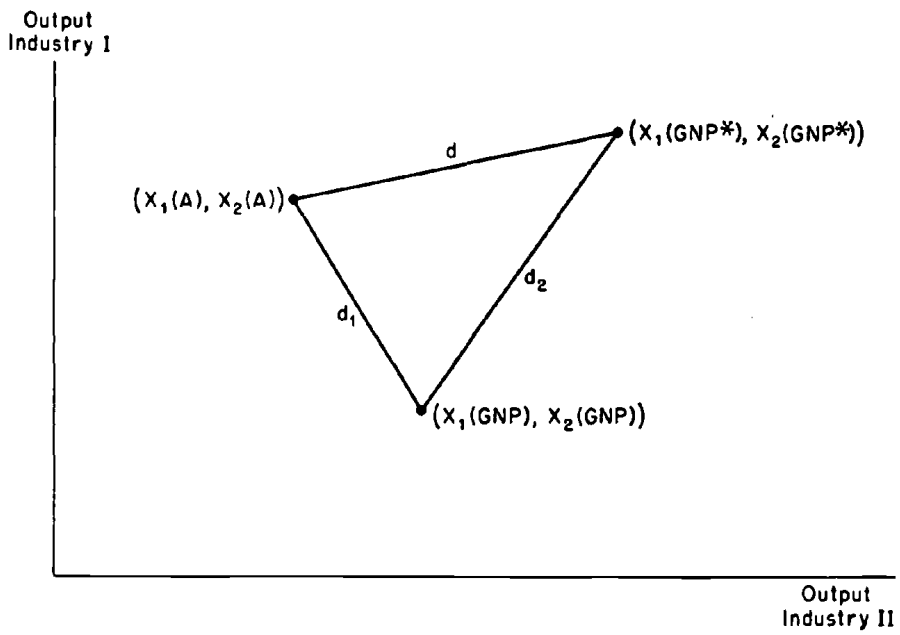

\section{Stanley Lebergott, Bureau of the Budget}

Mr. Barnett's paper represents an excellent departure from previous, a priori criticisms in the direction of an empirical evaluation of the input-output technique. It sets a course toward a richer understanding of what this technique offers for economic programming. It suggests the following lines of comment, among others:

1. By making one essential modification in Barnett's procedure, we find that the regression method produces estimates which are markedly better for these particular projections than those derived by the input-output approach.

Barnett's regression-estimating equation is based on 1922-41 and 1946 data. Since he is projecting to a peacetime year (Full Employment Patterns, 1950 assumed no war, a small army), he properly excludes the war years in making his equation. However, for aircraft, shipbuilding, and transportation, n.e.c., the years 1939-41 should also have been excluded. These were years of war preparation-first for the Allies and then for this country. Unless we exclude them, what do we do? For shipbuilding, we derive an estimating equation which tells us that the more ships we build, the more we have to build-this, because the 1939-41 values are so far above those for the first 25 years. ${ }^{1}$ For aircraft the infer-

${ }^{1}$ This arises, of course, because no allowance is made in this model for 
ences are even more anomalous: the equation indicates that by 1960 (or earlier) no aircraft will be produced in the United States. ${ }^{2}$ The aircraft estimate has a sizable negative trend term, resulting from a combination of (a) a time series with few observations (1932-41 and 1946) and (b) a terminal value-for 1946-some 40 percent below the previous 1941 value. The same general consideration is applicable to each transport industry: Years of extensive war preparation, like years of war output, should be excluded in projecting a peacetime level of production.

By excluding the three industries, we at once reduce the unweighted mean error of estimate for the regression technique to half the error for the input-output investment model and to threequarters of that for the input-output consumption model. (The weighted mean errors for the regression estimate were smaller than those for the input-output estimate even before this exclusion. $)^{3}$

2. The fact that the input-output estimate of production in agriculture and fishing was too great while its estimate for agricultural machinery was too small indicates one of those contradictions which the technique is designed to avoid. Moreover, for industries like petroleum production, coal, gas, and steam railroads-where the input-output contribution to the analysis of derived demand should be greatest-the input-output estimates were not better. In most instances they were worse. These facts suggest the importance of making all reasonable adjustments in the technical coefficients before using them for projecting-a possibility which time did not permit when the Full Employment Patterns, 1950 estimates were being made.

3. Regression estimating is not necessarily an alternative to the input-output approach. It may very well supplement that procedure. For by regression analysis we may be able to estimate the proper coefficients to use in input-output projections. For certain industries, the sales and production data are already sound enough; for others, crude attempts can be made. Such attempts deserve more attention than they have hitherto received as a

inventory accumulation. An additional term for this item would likewise have improved the estimate for motor vehicles.

2 Barnett's trend term is negative 114.52, while the 1950 aircraft index is 614. His coefficient for GNP is likewise negative.

${ }^{3}$ Such hand tailoring is parallel to the procedure of revising the 1939 coal and diesel consumption coefficients for railroads in making the 1950 input-output projections. 
means of securing coefficients which will subsume in a nonmeclianical way the joint effects of social change, of shifts in distribution patterns, and of shifts in production procedures which, interacting with more obvious technical and economic factors, bring about changes in the technical coefficients.

4. Mr. Barnett rightly emphasizes the role of sound guesswork -it can hardly deserve a more dignified name-in stipulating the final-demand figures. For this purpose, we do not need so much more as more current data on consumption patterns by income level, occupation, and/or class of worker. To the extent that we can secure monthly, quarterly, or even annual data on such patterns, and tabulate them with reasonable speed, we will have a much sounder basis for estimation than is possible given our current reliance on comprehensive, but outdated, survey results. 